Perspective

\title{
Sodium Toxicity in the Nutritional Epidemiology and Nutritional Immunology of COVID-19
}

\author{
Ronald B. Brown (D)
}

Citation: Brown, R.B. Sodium Toxicity in the Nutritional

Epidemiology and Nutritional Immunology of COVID-19. Medicina 2021, 57, 739. https://doi.org/ $10.3390 /$ medicina57080739

Academic Editors: Andrea Maugeri, Martina Barchitta and

Antonella Agodi

Received: 28 June 2021

Accepted: 19 July 2021

Published: 22 July 2021

Publisher's Note: MDPI stays neutral with regard to jurisdictional claims in published maps and institutional affiliations.

Copyright: (C) 2021 by the author. Licensee MDPI, Basel, Switzerland. This article is an open access article distributed under the terms and conditions of the Creative Commons Attribution (CC BY) license (https:// creativecommons.org/licenses/by/ $4.0 /)$.
School of Public Health Sciences, University of Waterloo, Waterloo, ON N2L 3G1, Canada; r26brown@uwaterloo.ca

\begin{abstract}
Dietary factors in the etiology of COVID-19 are understudied. High dietary sodium intake leading to sodium toxicity is associated with comorbid conditions of COVID-19 such as hypertension, kidney disease, stroke, pneumonia, obesity, diabetes, hepatic disease, cardiac arrhythmias, thrombosis, migraine, tinnitus, Bell's palsy, multiple sclerosis, systemic sclerosis, and polycystic ovary syndrome. This article synthesizes evidence from epidemiology, pathophysiology, immunology, and virology literature linking sodium toxicological mechanisms to COVID-19 and SARS-CoV-2 infection. Sodium toxicity is a modifiable disease determinant that impairs the mucociliary clearance of virion aggregates in nasal sinuses of the mucosal immune system, which may lead to SARS-CoV-2 infection and viral sepsis. In addition, sodium toxicity causes pulmonary edema associated with severe acute respiratory syndrome, as well as inflammatory immune responses and other symptoms of COVID19 such as fever and nasal sinus congestion. Consequently, sodium toxicity potentially mediates the association of COVID-19 pathophysiology with SARS-CoV-2 infection. Sodium dietary intake also increases in the winter, when sodium losses through sweating are reduced, correlating with influenza-like illness outbreaks. Increased SARS-CoV-2 infections in lower socioeconomic classes and among people in government institutions are linked to the consumption of foods highly processed with sodium. Interventions to reduce COVID-19 morbidity and mortality through reduced-sodium diets should be explored further.
\end{abstract}

Keywords: COVID-19; coronavirus; SARS-CoV-2; sodium toxicity; nutritional epidemiology; nutritional immunology; virology; pathophysiology; mucosal immune system; pulmonary edema

\section{Introduction}

Since coronavirus disease-2019 (COVID-19) was designated a pandemic by the World Health Organization on 11 March 2020 [1], there has been strong public demand for vaccines and pharmacotherapies to treat the disease [2], while modifiable dietary and nutritional factors for COVID-19 prevention remain relatively under-investigated. An urgent need has been identified for the research of non-drug interventions in COVID-19, including interventions for the modification of environmental disease risk factors [3]. As the potential for new outbreaks pose an imminent threat, the need for novel interventions is especially urgent for older adults in the high-risk category for morbidity and mortality from COVID-19 [4].

Still, a causal relationship may seem unlikely between dietary factors and COVID-19 etiology, an infectious influenza-like illness (ILI) [5] associated with severe acute respiratory syndrome coronavirus 2 (SARS-CoV-2). However, until the last few decades of the 20th century, causal relationships also seemed unlikely for dietary factors in non-communicable diseases like cancer and cardiovascular disease, the leading causes of death globally [6], but diet and nutrition research has since emerged in these areas and accelerated to the present [7]. Similarly, emerging evidence suggests that sodium toxicity, the toxic effect in the body caused by dysregulated amounts of the essential dietary micronutrient sodium [8,9], has potential causal influences in the etiology of ILIs like COVID-19. 
A high sodium intake is a dietary risk factor associated with multiple diseases, and it is estimated to have caused a mean of 3 million deaths globally in 2017 [10]. Several of these diseases have also been identified as underlying conditions associated with increased risk for COVID-19 morbidity and mortality, implying a causal link to sodium toxicity through transitive inference. Recently, nutritional status has been proposed to provide potential immunomodulary and anti-inflammatory benefits in COVID-19 and its comorbidities [11]. Nutritional immunology is a new discipline that studies the interplay between food and food components with immune responses and disease prevention [12]. The World Health Organization listed immunocompromised status and nutritional status as factors that increase susceptibility to infection [13]. The current need to identify the toxicological mechanisms associated with COVID-19 also remains urgent [14].

This article reviews a wide variety of research findings with the aim of synthesizing evidence of sodium toxicity as a modifiable dietary factor associated with the nutritional epidemiology and nutritional immunology of COVID-19 and SARS-CoV-2 infection. Grounded theory was used as a method to review the literature, which added scholarly rigor and objectivity when researching and writing this perspective paper [15]. The selected data consisted of research findings and evidence-based concepts from relevant knowledge domains, including epidemiology, virology, immunology, and clinical pathophysiology. Data were searched for using Google, Google Scholar, PubMed, and Scopus, as well as other books, journals, and databases available through the University of Waterloo Library. Starting with a clean slate to remove subjective opinions and assumptions, rigorous comparative analysis was used to scrutinize the literature and logically connect evidence-based findings into causative, associative, and mediating relationships. A more detailed description of this method is explained in a source written by the present author [16]. As categorical themes inductively formed through iterative analysis, theoretical saturation was reached in this paper (when no more new knowledge was obtained). The final result is a coherent and novel explanatory grounded theory linking sodium toxicity to the etiology of COVID-19 and SARS-CoV-2 infection. The paper proceeds with an overview of viral infection.

\section{Current Perspective of Viral Infection}

The basic structure of a virion consists of a piece of nucleic acid surrounded by a protein capsid [17]. Currently, the human virome is the most recently studied part of the human microbiome, but knowledge and research technology in this area are limited [18]. Distinctive viromes have been identified in the gastrointestinal tract, salivary glands, and respiratory tract. However, it is unclear which viruses have detrimental or beneficial effects on human health, and the molecular and physiological mechanisms of these effects are unknown. Whether a virus is harmful or harmless can depend on the immunological status and health of the host [19].

An analysis of the transcriptomic architecture of SARS-CoV-2, which analyzes how the genes of the coronavirus are translated from a single strand of ribonucleic acid (RNA), found that the shortened tails of the virus might represent aged and decay-prone RNA (as in disposable genetic waste products), similar to the type of RNA generated by the mitochondria [20]. Mitochondria organelles in cells contain their own disposable mitochondrial deoxyribonucleic acid (mtDNA), which is densely packed in nucleoids, separate from the genes in the cell nucleus [21]. The tight density of mtDNA packing is similar to the density of DNA tightly packed into the capsid of a papillomavirion [22]. The turnover of mtDNA has a relatively brief half-life, and degraded mtDNA may be abandoned without noticeable physiological harm to the mitochondria. Mammalian somatic cells can contain up to 2000 mitochondria per cell [23], with each mitochondria potentially contributing genetic waste products. Additionally, bacteria in the microbiome contain chromosomal DNA packed in a nucleoid [24], which can also contribute to genetic waste when the cell expires.

Cells have waste removal and recycling mechanisms that manage genetic waste products [25]. Proteins labelled with ubiquitin are targeted and broken down by proteasomes for reuse in synthesizing new proteins. Lysosomes contain digestive enzymes to breakdown 
organelles and viruses during the process of autophagy, and collected piles of unwanted cellular trash form aggregates, which might explain the formation of viral aggregates [26]. Extracellular vesicles (EVs) are also formed, and cargo is loaded and released by cells to function as a waste management mechanism that removes intracellular debris [27]. In pathological conditions, EVs may not clear promptly from circulation, contributing to the underlying pathology.

Some EVs may resemble the structure and function of viruses, carrying viral proteins and genome fragments that make these EVs indistinguishable from "noninfectious" or "defective" viruses, which do not fit the prevailing definition of infectious viral agents that multiply exclusively in living cells [28]. Genome fragments in EVs include discarded messenger RNA (mRNA), a genetic messenger molecule [29]. Importantly, both nuclear and mitochondria mRNA undergo degradation after having been translated during protein synthesis [30,31], and very small EVs called exosomes have been found to transport mostly mRNA fragments [32].

Evidence of the role played by noninfectious viruses in pathogenesis is considered "very limited" and "obscure" by textbook authors writing on virus replication [33]. However, the biological process of natural infection is much more complex than the oversimplified depiction in textbooks. For example, even though noninfectious viruses make up most of the viral population in influenza A infection, the range of biological activity attributed to noninfectious viruses, including self-aggregation, has been understudied and "does not necessarily imply a defect of any kind" [34]. Furthermore, nucleic acid detection of high viral loads in clinical specimens collected during a pandemic cannot distinguish between noninfectious viruses and viruses that are assumed to be proliferating, nor is detection of viral RNA in specimens always correlated with viral transmissibility [35].

A recent discovery found that complete genomic mtDNA can be harbored in EVs [36], providing further evidence of a transport mechanism in which genomic debris is circulated for waste clearance, and which may contribute to the pathology if the waste is allowed to accumulate as an aggregate. Collective viral spread by virion aggregates helps a viral infection overcome infection barriers [37], which raises the possibility that the observed association of multiplication with viral infection could be caused by viral aggregation from accumulated waste products. For example, in a viral replication experiment, viruses added to cultured cells disappeared and reappeared later as progeny [33]. However there are potential flaws in this "proof of concept" experiment. Virion particle breakdown and recycling by the cultured cells' immune response could explain the "remarkable" disappearance of the viruses, and gradual accumulation of the cultured cells' own genetic waste products, i.e., exosomes containing genome fragments, could explain the putative reappearance of a viral progeny. Furthermore, no comparisons with the results from control groups were mentioned in this "experiment."

An infectious virus is claimed to hijack a host cell's DNA reproductive mechanisms in order to translate the virus genome and replicate the virus [38]. However, the genetic code in the mRNA, which is a transcribed message destined for delivery to the ribosomes, can only be used to translate the biogenesis of harmless proteins needed by the cell. Translation of the coded genetic message in mRNA fragments does not replicate the mRNA itself, making the fragments noninfectious. Similarly, RNA in SARS-CoV-2 contains 29,811 nucleotides that encode 29 proteins, most of which are unrelated to the structure of mRNA itself [39], implying that the virus, composed of noninfectious mRNA fragments, is itself noninfectious. If true, this further implies that SARS-CoV-2 cannot replicate within a host. The presence of noninfectious viruses could also explain why viral RNA is detected in a host even if a viral infection is not present [40]. In addition, mutations claimed to occur in influenza viruses are reassortments of RNA fragments, often packaged in groups of eight fragments, and more knowledge of the mechanisms in genome packaging is needed [41]. Furthermore, single virions are rarely sufficient to establish infections, and the dispersion of multi-virion structures in infection remain poorly understood, needing more study in this area of virology [42]. 
EVs, including apoptotic bodies, exosomes, and microvesicles, are also responsible for the transmission of biomolecules in the development of sepsis [43]. Viral sepsis has been proposed as a critical immunopathological mechanism in COVID-19, based on findings of significantly elevated levels of cytokines, chemokines, and other immunological response agents in COVID-19 cases-part of a cytokine storm often seen in severe influenza infections [44]. Sepsis from infection is a complicated syndrome of pathophysiological mechanisms that are not yet fully understood. A little less than half of sepsis cases have non-bacterial causes, and viral sepsis is more often seen in immunosuppressed patients [45].

The above evidence raises the intriguing possibility that SARS-CoV-2 may be associated with endogenous genetic waste products. By contrast, no causal evidence supports a zoonotic transmission of exogenous viruses in COVID-19 [46]. About half of COVID19 cases reported diarrhea and digestive symptoms in Wuhan, Hubei Provence, China, where SARS-CoV-2 was first detected in wet markets [47]. Gastrointestinal symptoms are highly unusual and inconsistent with the low amount of these symptoms in patients with severe acute respiratory syndrome (SARS) or Middle East respiratory syndrome (MERS) [48]. Although gastrointestinal symptoms are associated with the consumption of wild animal products [49], there is no causative evidence linking exposure to wild animal products and zoonotic transmission of SARS-CoV-2 from bat SARS-related coronavirus (bat SARSr-CoV) [50]. Of relevance, a study of Dietary Approaches to Stop Hypertension (DASH) found that a high dietary sodium intake was associated with a $27 \%$ increased risk of gastrointestinal bloating, compared with a $41 \%$ increased risk of bloating associated with a high dietary fiber intake [51]. Bloating from high dietary sodium was independent of dietary fiber intake in the study.

Briefly summarizing the reviewed evidence so far, there are many unknowns in the field of virology that require further investigation. Reviewed evidence in this article supports the mechanisms that excrete and transport endogenous waste products that have the potential to contribute to infectious disease pathophysiology. Of particular interest, viral infections are established by virion aggregates, not single virions, and viral aggregates may form from the undisposed waste products of cells. Furthermore, testing is insufficient to provide proof that the detection of viral RNA in specimens always correlates with viral transmissibility and viral proliferation in ILIs. The remaining sections of this article synthesize the transdisciplinary evidence from virological, immunological, pathophysiological, and epidemiological determinants, linking the molecular mechanisms of sodium toxicity with COVID-19.

\section{Risk Factors Associated with COVID-19}

Most viral infections are associated with other disease-causative agents, in addition to the viral infection itself [52]. Evidence suggests a somewhat independent relationship may exist between a viral infection and disease-causative agents. For example, a weak presence of disease-causative agents could explain why asymptomatic people with detected exposure to SARS-CoV-2 infections do not develop clinically significant disease symptoms. Conversely, a strong presence of disease-causative agents could explain why antibodies from SARS-CoV-2 infection alone may be insufficient to prevent severe disease symptoms in people who are reinfected with SARS-CoV-2 [53].

China and Italy were among the first countries to experience severe outbreaks during the COVID-19 pandemic. Hypertension was identified as a risk factor associated with severe cases of COVID-19 in China and Italy [54]. Of relevance, hypertension was found to be a risk factor associated with mortality in both the 2009 (H1N1) swine influenza pandemic [55] and the 2013 avian influenza A (H7N9) virus infection [56]. Hypertension risk is also associated with a high dietary sodium chloride intake [57], and China is among the highest consumers of sodium chloride in the world [58]. Almost half of the Chinese population between 35-75 years of age has hypertension, most of which is untreated and uncontrolled [59]. Italy also ranks high among consumers of sodium chloride [60], and 
hypertension prevalence in Italy affects up to $59 \%$ of the population over 18 years of age [61].

In addition, Italy has a large ageing population with underlying health conditions, associated with an increased case fatality rate in COVID-19 [62]. Further studies are needed to investigate the population sodium intake associated with severity of COVID-19 outbreaks by country or region. Other large countries with a high sodium intake include India, the United States, Australia, Canada, and England [63].

Cases of COVID-19 in the research literature have been associated with stroke [64], thrombosis [65], cardiac arrhythmias [66,67], obesity [68], diabetes [69], kidney disease [70], hepatic disease [71], multiple sclerosis [72], systemic sclerosis [73], migraine [74], tinnitus [75], Bell's palsy [76], polycystic ovary syndrome [77], and pneumonia [78]. Incidentally, the coronavirus discovered in Wuhan, China, in December 2019 was first detected in cases of novel coronavirus-infected pneumonia (NCIP) [79]. Likewise, high sodium chloride intake and sodium concentration levels are risk factors associated with stroke [80], thrombosis [81], cardiac arrhythmias [82,83], obesity [84], diabetes [85], kidney disease [86], hepatic disease [87], multiple sclerosis [88], systemic sclerosis [89], migraine [90], tinnitus [91], Bell's palsy [92], polycystic ovary syndrome [93], and pneumonia [94], providing clinical evidence that these diseases form a transitive link between COVID-19 and a high sodium chloride intake. Transitive inference is a comparative analysis tool described in the present author's previous work [16]. Inferred transitive links are not strong enough to prove causation, but these links are useful for exploring unknown areas and identifying related subjects for further research. In addition, pediatric Kawasaki-like symptoms associated with COVID-19 have been reported, known as multi-system inflammatory syndrome in children (MIS-C) [95]. As in COVID-19, MIS-C and Kawasaki-like symptoms have also been associated with hypertension [96], stroke [97], acute heart failure [98], and acute kidney injury [99], transitively linking sodium toxicity to pediatric disease pathophysiology. Although other dietary, environmental, and lifestyle factors are relevant to the pathophysiology of COVID-19, numerous transitive links with COVID-19 suggest that sodium toxicity may be among the leading factors potentially contributing to the disease.

Excessive sodium intake leading to sodium toxicity exceeds the human body's minimum requirement of $500 \mathrm{mg}$ sodium needed to function properly [100], which can be provided from natural foods without added sodium chloride. Sodium chloride contains about $40 \%$ sodium by weight, and Americans consume excessive sodium, averaging 3300 $\mathrm{mg}$ a day [101]. Although sodium chloride is an ionic compound that dissolves into separate sodium and chloride ions in an aqueous state, electrolysis is required to overcome the electrostatic force connecting sodium and chloride ions in a brine solution, producing poisonous chlorine gas [102]. No evidence exists that electrolysis naturally occurs within the human body to convert sodium chloride to free sodium ions and free chloride ions for physiological functions, such as ion passage through individual ion channels in cell membranes that select only one type of ion [103]. In addition, observational studies claiming increased mortality associated with a low sodium intake were challenged for having research design flaws, such as selection bias from not excluding seriously ill patients, and information bias from poor data collection of the daily sodium intake [104,105].

When the body content of water and sodium are excessively high in edematous conditions, hyponatremia (serum sodium levels $<135 \mathrm{mEq} / \mathrm{L}$ ) is caused by dilution from an osmotic shift of water out of cells [106-108]. Called hypervolemic hyponatremia, this type of hyponatremia is often treated with diuretics and the restriction of fluids and sodium. Hypervolemic hyponatremia should be differentiated from other types of hyponatremia where the body water content is low, as in hypovolemic hyponatremia, and the water content is normal, as in euvolemic hyponatremia. Disconcertingly, out of a dozen recent articles reporting adverse outcomes and increased mortality in COVID-19 patients with hyponatremia [109-120], only two of the articles mentioned hypervolemic hyponatremia $[115,119]$. Moreover, none of the studies in the 12 articles stratified patients by hyponatremia type. Further research is needed to clarify the prevalence of hypervolemic 
hyponatremia associated with high water and sodium levels in COVID-19 patients. Of relevance, hyponatremia that occurs in syndrome of inappropriate antidiuretic hormone secretion (SIADH), also reported in COVID-19 patients [115], results from excess water rather than sodium deficiency [121].

Normally, excess sodium is excreted by the kidneys, with additional losses through the skin and gastrointestinal tract, but a high sodium chloride intake may overload renal nephrons with excessive pressure and volume, causing a decline in the glomerular filtration rate [122]. Burdened renal function is associated with impaired sodium excretion, as in chronic kidney disease [123], which may gradually increase the development of sodium toxicity in the body tissues. No specific level of sodium intake has been associated with sodium toxicity. However, according to the U.S. Department of Agriculture and U.S. Department of Health and Human Services' Dietary Guidelines for Americans 2020-2025, the daily sodium chronic disease risk reduction limit for adults is $2300 \mathrm{mg}$ [124], implying that daily sodium intake above this level may increase risk of toxic or pathogenic effects. Lethal dietary sodium levels for some adults (just under four tablespoons of sodium chloride) are almost twice the upper range consumed by some people in China [125]. Although evidence has not previously linked sodium chloride as an associated risk factor for infectious respiratory diseases like COVID-19, a high sodium chloride intake has been associated with severe noninfectious chronic respiratory diseases such as asthma [126] and chronic bronchitis [127].

Evidence associating sodium toxicity with thrombosis and stroke in COVID-19 patients is grounded in research findings linking thrombosis to elevated serum sodium in mice, mediated by vascular endothelial cell secretion of the blood-clotting factor, the von Willebrand Factor (vWF) [81]. Researchers have also found that elevated sodium chloride increases vWF secretion in vascular endothelial cell cultures, and analysis of the data from the Atherosclerosis Risk in Communities Study revealed that serum sodium is associated with plasma vWF and stroke risk.

\section{SARS-CoV-2 Infection and Sodium Toxicity}

The cells of the respiratory system are susceptible to infection through exposure to viruses and other pathogens; however, a non-specific innate immune response and an adaptive immune response eliminates viruses and protects respiratory cells from infection [128]. As part of the mucosal immune system, the nasal mucosa provides physical protection against dehydration and injury from mechanical and chemical agents, and provides the clearance of particles and microorganisms [129].

However, sodium toxicity adversely affects the nasal mucosal immune system, which may lead to respiratory viral infection. For example, hypertonic concentrations of $2 \%$ sodium chloride were used in vitro to experimentally induce ciliostasis, paralyzing cilia beating in the nasal mucosa epithelial cells, which normally transport the mucous out of the airways. When the epithelial cells were infected with influenza A virus, the viral yield in the saline-treated cells increased two- to three-fold compared with the untreated cells, demonstrating that normally beating cilia impede viral infection [130]. Although $2 \% \mathrm{NaCl}$ in these experiments is 2 -fold and 20 -fold higher than normal extracellular and intracellular concentrations, respectively, findings may be translated bench-to-bedside for more moderate clinical applications. Specifically, moderately impaired function of the cilia caused by sodium toxicity could inhibit mucociliary clearance, leading to increased accumulation of viruses in patients' nasal passages, as detected in laboratory analyses of nasopharyngeal swab specimens collected during COVID-19 testing [131]. COVID-19 patients were found to have prolonged mucociliary clearance compared with healthy ear, nose, and throat outpatients with non-nasal symptoms [132]. Furthermore, the upper nasal passages are a potential portal allowing viruses and other particles to enter the bloodstream, eventually leading to viral sepsis [44]. Of relevance, other research has found that an increased concentration of plasma sodium in the hypernatremia was significantly 
associated with sepsis in elderly patients [133]. This evidence could explain sepsis in COVID-19 patients associated with sodium toxicity [44].

No difference in viral load was found in asymptomatic infections of SARS-CoV-2 and infections with symptoms in Lombardy, Italy [134], and no viral load differences were found across patient gender, age, and disease severity in Guangzhou, China [135]. This evidence suggests laboratory confirmed viral infections of SARS-CoV-2 and clinical symptoms of COVID-19 may have separate causative pathways, which would explain why they do not always appear together. For example, asymptomatic infections occur without clinical symptoms [136], and clinical symptoms in post-acute COVID-19 syndrome persist after the acute infection stage subsides [137]. These facts support a hypothesis proposing that the association of COVID-19 and SARS-CoV-2 is mediated by a related disease determinant. On the other hand, compared with mild cases, the mean viral loads were 60 times higher in the nasal passages of cases associated with the most severe symptoms in Nanchang, China [138], which could be related to severely impaired viral clearance in the nasal mucosal immune system due to excessively strong sodium toxicity. Of relevance, the viral clearance was delayed and clinical outcomes did not improve when corticosteroids were used to treat SARS-1 patients [139], and corticosteroids cause retention of sodium [140]. Likewise, the French Health Ministry suggested that ibuprofen aggravates infection in COVID-19 [139], and non-steroid anti-inflammatory drugs (NSAIDs) like ibuprofen cause sodium and water retention [141].

\section{Sodium Toxicity and Immune Response in COVID-19}

Sodium chloride intake is associated with changes in immune responses that promote organ damage and inflammation, including increased release of inflammatory cytokines, like interleukin (IL)-6, macrophage inflammatory protein-2 (MIP-2), and tumor necrosis factor (TNF)- $\alpha$ [142]. Elevated sodium chloride concentrations also increase the proliferation of T-cells, while decreasing the anti-inflammatory responses-for example, anti-inflammatory M2 macrophages are suppressed while pro-inflammatory M1 macrophages are increased by high sodium chloride levels. Furthermore, sodium chloride was found to enhance the production of IL- 4 and IL-13, and to suppress the production of interferon- $\gamma(\mathrm{OFN}-\gamma)$ in memory T cells [143]. Interleukin-17 (IL-17)-producing helper T cells (Th17) play a role in clearing the extracellular pathogens, and Th17 cell development is induced by a kinase signaling pathway activated by high sodium chloride concentrations [144].

Researchers have reported that a "high-salt diet promotes skin Na+ accumulation, which boosts macrophage activation", leading researchers to "speculate" that cutaneous sodium storage provides a barrier against infection [145]. However, researchers have also noted "that skin $\mathrm{Na}+$ deposition is linked with disease in humans". Alternatively, macrophage activation suggests an inflammatory immune response to salt-induced tissue damage, as "high-salt diets result in interstitial hypertonic $\mathrm{Na}+$ accumulation in the skin and muscle that activates tissue-resident macrophages" [146].

The secretion of cytokines in response to RNA viruses, like SARS-CoV-2, include TNF- $\alpha$ and IL-6, with a general imbalance toward pro-inflammatory responses in contrast with antiviral responses [147], similar to the responses to sodium toxicity. Resilient T cell immunity is necessary for the efficient control of viruses, and $\mathrm{T}$ cell counts in COVID19 patients with mild symptoms were found to be normal or a bit higher-again, an immune response similar to sodium toxicity. However, $\mathrm{T}$ cell counts were reduced in moderate and severe cases, suggesting that the $\mathrm{T}$ cell response is dysregulated in severe cases, possibly because of exhaustion from over-activation. This reduction in $\mathrm{T}$ cell counts could be related to severe sodium toxicity, and more investigations are needed in this area. Of relevance, human receptor angiotensin-converting enzyme 2 (ACE2) is a binding site for SARS-CoV-2, and ACE2 is found in the membranes of alveolar macrophage cells in the respiratory tract and in other cells throughout the immune system [148], potentially providing a protective mechanism that facilitates endocytosis and the lysis of pathogens. However, this protection could be compromised, as ACE2 expression is reduced under 
conditions of high sodium chloride dietary intake, as was found to occur in the renal system in animal experiments [149]. In addition, based on the studies of other human coronaviruses, humoral responses to coronavirus infection are comparatively short-lived and provide only partial protection from reinfection. Considering the failure to find a cure for coronavirus infections in the common cold after many decades of research [150], the potential for newly developed vaccines to eliminate the virus and its variants does not portend well [151].

\section{Sodium Toxicity and COVID-19 Symptoms}

COVID-19 symptoms include fever, dry cough, fatigue, headache, and nasal congestion, and more serious symptoms include difficulty breathing [152]. Regardless of whether symptoms are due to acute cases or long-haul COVID-19 [153], sodium toxicity may play direct and indirect roles in many of these symptoms. In 1969, a controlled clinical trial tested the hypothesis that large infusions of sodium chloride and water would prevent fluid loss and hypovolemia related to complications in thoracic surgery [154]. After receiving sodium chloride infusions, some patients rapidly developed severe pulmonary congestion and fluid retention in the lungs, or pulmonary edema, which blocked respiration and lowered arterial oxygen pressure $\left(\mathrm{pO}_{2} ;\right.$ Figure 1$)$. One patient in the study died, and other patients who received infusions containing various concentrations of sodium chloride were placed on ventilators. These clinical experimental results demonstrate the harm of excessive sodium chloride and retained fluid in the lungs, causing pulmonary congestion, hypervolemia, and edema. The chest X-ray taken after sodium chloride infusion (b) is similar to the radiographs of drownings [155].

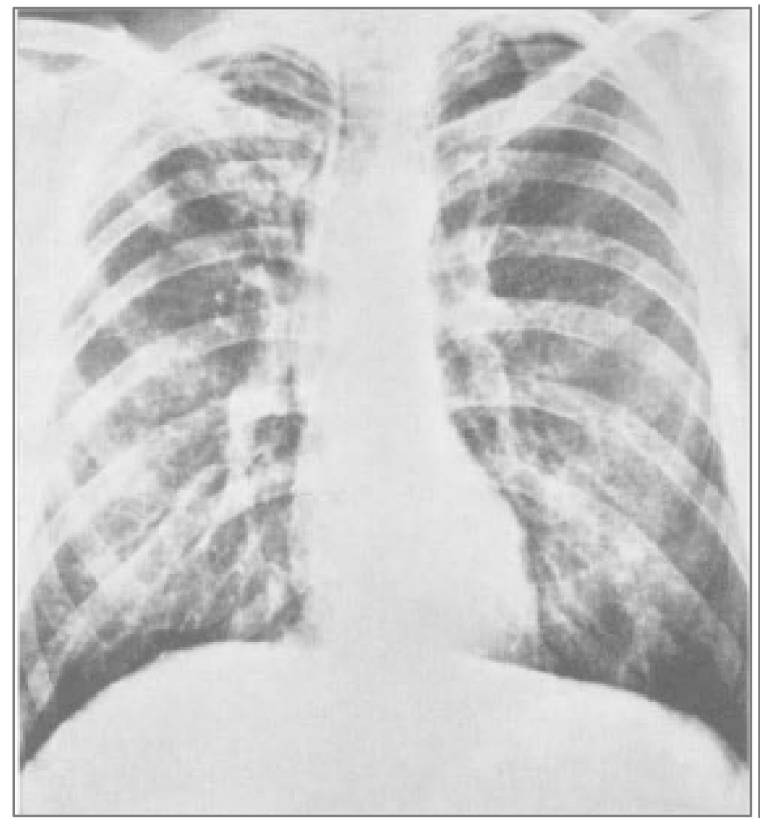

(a)

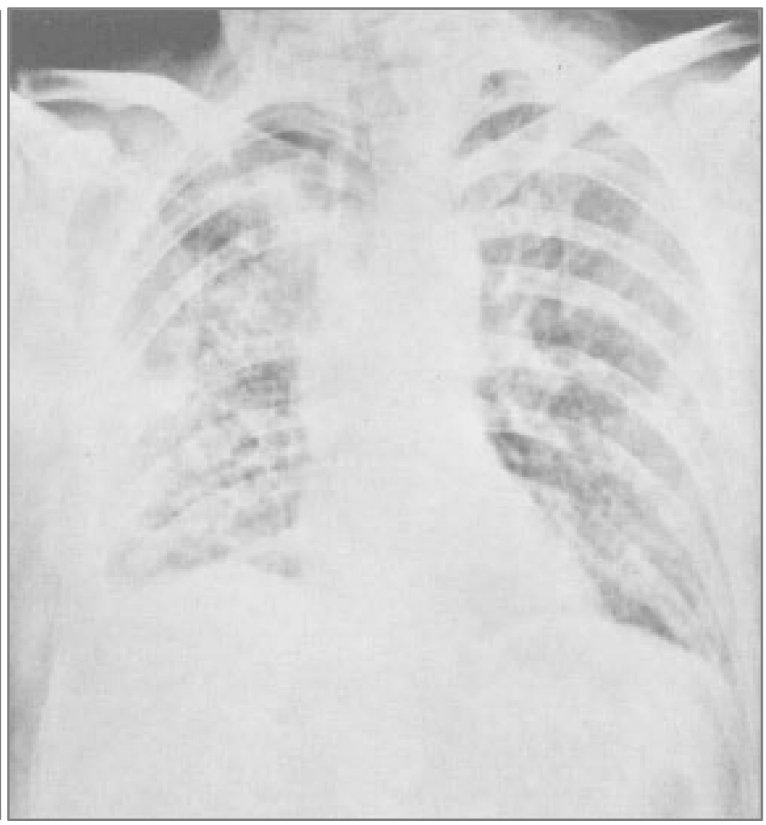

(b)

Figure 1. Pulmonary congestion following sodium chloride infusion. (a) Patient before a large infusion of sodium chloride and water in a 1969 controlled clinical trial. (b) Same patient two days after infusion, showing severe congestion from pulmonary edema due to fluid retention. Reprinted from Hutchin et al., 1969 (132). Pulmonary congestion following infusion of large fluid loads in thoracic surgery patients, The Annals of Thoracic Surgery, 8(4), 339-347, with permission from Elsevier.

Ground-glass opacities are often observed in the lungs of COVID-19 patients [156], and further research is needed to investigate whether related fluid in the lungs may increase to harmful levels in COVID-19 patients if sodium is retained under conditions of sodium toxicity. A recent review of fluid therapy in thoracic surgery confirmed that 
aggressive fluid infusion promotes hypervolemia, interstitial edema, and impaired oxygen diffusion [157], and the aggressive accumulation of fluid is associated with mortality and acute kidney injury in pneumonia from influenza A H1N1 virus [158]. The clearance of alveolar edema fluid requires active transport of sodium out of the airspaces, with water removal following the osmotic concentration gradient [159]. Intraperitoneal injection of distilled water $(1500 \mathrm{~mL})$ and glucose have been reported to help in the recovery of acute salt poisoning cases [160], probably by reducing the hypertonicity of the extracellular fluid caused by concentrated levels of sodium.

Clinical evidence from a retrospective cohort study in Wuhan, China, shows that acute respiratory distress syndrome (ARDS) is a risk factor for mortality associated with SARS-CoV-2 [161]. ARDS shares symptoms of severe shortness of breath with COVID-19, yet the causes listed for ARDS do not include viral infections [162]. Italian physicians noted that ARDS is not typical in COVID-19 patients compared with other ARDS patients [163], and ventilation may do more harm than good. For example, in Fluid Management in the Ventilated Patient, Bersen wrote,

“... various neurohumoral responses to positive-pressure ventilation lead to retention of sodium and water, as a homeostatic response to raised intrathoracic pressure. A major consequence of this response is expanded plasma volume, and a tendency toward systemic and pulmonary edema [164]."

The air sacs of the lungs in fatal cases of COVID-19 with ARDS were reported to become filled with a gummy yellow fluid that blocked the transfer of oxygen to the blood from the lungs, even though a ventilator was pumping in oxygen [165]. Under these conditions, adjusting ventilation to force in higher amounts of oxygen under greater pressure can damage the lungs. In-hospital mortality in critically ill COVID-19 patients increased with high frequency use of ventilators in two major hospitals in New York City [166]. Non-invasive ventilation procedures that cause less lung damage have since gained "a more significant and positive role" in treating COVID-19 patients [167]. Furthermore, the gummy yellow fluid in the lungs of COVID-19 patients appears identical to the yellow fluid identified in pulmonary edema [168]. Pleural effusion is also a pulmonary condition observed in Kawasaki Disease [169]. Although other factors like toxins and medications are linked to pulmonary edema [170], the above findings strengthen the link between pulmonary edema and COVID-19. Furthermore, because sodium toxicity is also linked to pulmonary edema, a potential transitive link is established between sodium toxicity and ARDS in COVID-19 patients.

In view of the potential harm from pulmonary edema that may be related to sodium toxicity, adverse effects from administering intravenous saline in patients with ILIs like COVID-19 warrant further investigation. Warnings from the U.S. Food and Drug Administration for $0.9 \%$ sodium chloride parenteral intravenous injection include "risk of solute overload causing congested states with peripheral and pulmonary edema" [171]. Serious adverse effects of normal saline solution also include shortness of breath, joint pain, rash, fever, and tachycardia [172]. Favorable outcomes that reduced death and renal dysfunction were found when switching intravenous fluids from saline to balanced crystalloid fluids, especially in cases of sepsis [173]. Additionally, almost a quarter of COVID-19 patients have acute heart failure, half of whom have no history of hypertension or cardiovascular disease, and aggressive fluid treatment is not recommended in these cases [174]. Furthermore, earlier research reported that patients having a type of acute heart failure with pulmonary edema had severe dyspnea, tachycardia, alveolar edema, and reduced arterial oxygen saturation, and adverse side effects of diuretic therapy in these cases were related to poorer outcomes [175].

Other ILI symptoms associated with sodium toxicity in COVID-19 are related to hypervolemia, or fluid overload, a condition of excess sodium and water in the blood, which expands the extracellular fluid compartment in the body [176]. Hypervolemia most commonly manifests as edema, and sodium restriction is essential for avoiding this condition. The World Health Organization reported that blocked sinuses in acute sinusitis 
fill with fluid and can cause headaches [177]. The edema of the nasal mucosal is a clinical feature of acute rhinosinusitis or inflammation of the nasal sinus mucosa, which is claimed to be caused by viruses [178]. The association of viral infections with rhinosinusitis may be mediated by sodium-induced hypervolemia and nasal mucosal edema, which could explain why nasal congestion and headache is associated with SARS-CoV-2 infection under conditions of sodium toxicity [90,179-182].

Migraine is associated with COVID-19 [74]. Researchers have demonstrated increased sodium permeability through the blood-brain barrier and blood cerebral spinal fluid barrier during migraine [90], and future research should investigate an association between this mechanism and sodium dietary intake. Dysregulated voltage-gated sodium channels are proposed to increase neurovascular compression on the roots of trigeminal cranial nerve fibers and cause migraine pain [179], and an association between this dysregulated mechanism with dietary sodium intake should also be investigated. On the other hand, an inverse association was found between dietary sodium intake and migraine $[180,181]$, although researchers cautioned against treating migraine patients with sodium [182]. Further research is needed to more fully investigate the relationships between dysregulated sodium, dietary sodium intake, and migraine.

Loss of the sense of taste, ageusia, and smell, anosmia, also occurs in COVID-19 [183], which may result from blocked sensory olfactory receptors in congested nasal tissue related to sodium toxicity. Edematous congestion may also contribute to peripheral nerve compression and entrapment, causing nerve damage [184], as in Bell's palsy induced by compression from saline injection [92].

Furthermore, animal studies have shown that injected sodium chloride acts as a pyrogen that causes fever, which researchers have suggested was induced by an imbalance between sodium and calcium ions in the anterior hypothalamus that controls hyperthermia [185]. As well as acting as an emetic that induces vomiting [186], adverse effects of pharmaceutical sodium chloride tablets include fever and rashes [187]. Skin rashes are dermatologic manifestations of COVID-19 [188], and higher salt concentrations were found in the skin of people with atopic dermatitis [143]. Thus, sodium toxicity accounts for many of the symptoms of ILIs like COVID-19. Figure 2 summarizes how sodium toxicity potentially mediates the association of SARS-CoV-2 and COVID-19.

Of relevance, normal saline $(0.9 \%)$ was used in placebo injections during randomized controlled trials for mRNA COVID-19 vaccines [189]. Just as very small amounts of certain foods, drugs, and environmental antigens can trigger hypersensitivity reactions in some people [190], small $0.3 \mathrm{~mL}$ saline injections could trigger mild hypersensitivity in apparently healthy people with underlying sodium toxicity. With over 15,000 to 20,000 placebo participants in the Moderna and Pfzier/BioNTech trials, respectively [191,192], a very small percentage of participants affected with mild hypersensitivity to saline, having adverse effects similar to COVID-19 symptoms [172], could potentially confound the trial results. Furthermore, the mRNA vaccines contain polyethylene glycol (PEG) [189], which has immunosuppressive and anti-inflammatory effects [193] that could suppress mild hypersensitivity reactions to saline used to reconstitute the Pfizer vaccine [194]. These issues should be explored further. 


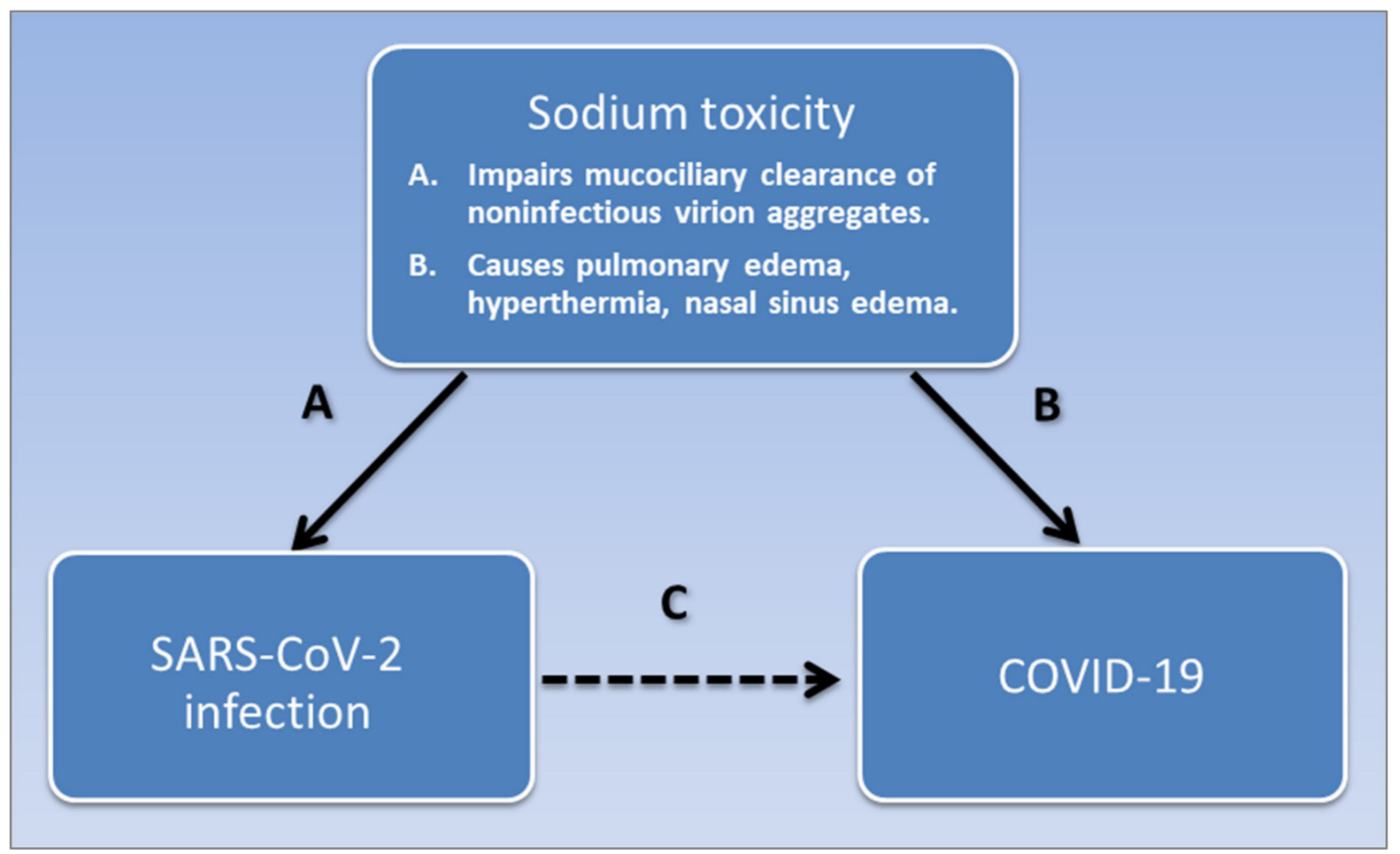

Figure 2. Sodium toxicity potentially mediates the association of SARS-CoV-2 infection and COVID-19. SARS-CoV-2 is associated with COVID-19, shown in pathway C. Sodium toxicity is a common causative factor that impairs the mucociliary clearance of noninfectious virion aggregates in the nasal mucosa, causing SARS-Cov-2 infection, shown in pathway A. Sodium toxicity also causes pulmonary edema, hyperthermia, and nasal sinus edema in COVID-19, shown in pathway B. Pathway A is potentially weak or absent in post-acute COVID-19 syndrome, and pathway B is potentially weak or absent in asymptomatic infections.

\section{Determinants of Sodium Toxicity}

Seasonal ILI epidemics annually claim hundreds of thousands of lives across the globe [195]. Seasonal changes in sodium balance, related to sodium dietary intake and excretion, are associated with sodium toxicity, which may help explain seasonal incidence of influenza and ILIs such as COVID-19. A recent study of seasonal influenza mortality found significant inverse associations with temperature, sunlight, and precipitation, supporting influenza patterns during late winter and early spring in temperate climates, and influenza patterns during the rainy season in subtropical and tropical climates [196]. Seasonal changes in behavior have also been proposed to account for non-environmental effects on seasonal influenza [197]. For example, research in Israel found that workers generally gained bodyweight and consumed over $40 \%$ more sodium chloride in the winter compared with summer [198]. Sodium intake also increased in winter in older adults in Turkey [199], in adults in Southern Brazil [200], and in a middle-aged and elderly Dutch cohort [201]. In Japanese hypertensive outpatients, 24-h urinary sodium chloride excretion, a reliable biomarker of sodium intake, generally decreased in the summer [202]. Other seasonal nutritional factors related to increased food intake, including seasonal changes in body mass index and waist circumference [203], may increase vulnerability to illness, such as the excessive consumption of dietary fat and carbohydrates for energy and heat maintenance during colder seasons. Of relevance, grains, baked goods, and meats, which are relatively rich in carbohydrates and/or fats, contribute the majority of sodium chloride to the American diet [204].

Climate is also associated with the prevalence of COVID-19; for each one-degree increase in latitude from the equator, the associated prevalence of COVID-19 cases increases by $4.3 \%$ per one-million inhabitants [205]. Increasing latitude is also associated with 
multiple sclerosis (MS) in U.S. women [206] and, as previously mentioned, MS is associated with both COVID-19 and dietary sodium [72,88]. Although a prospective study found no association between sodium intake and MS [207], the study did not compare a high-sodium diet with a low-sodium diet containing $<1500 \mathrm{mg}$ sodium, as recommended by U.S. health authorities [208]. Furthermore, populations in East Asia, South East Asia, and South Asia have been reported to have lower MS incidence and prevalence, despite a high sodium intake; however, flaws and weaknesses in the diagnosis and data collection methods in these areas encumber accurate MS surveillance [209].

Males working in moderately hot conditions for an average of $10 \mathrm{~h}$ lost 4.8 to $6 \mathrm{~g}$ of sodium through sweat [210]. People eating a high-salt diet excrete more sodium in sweat than people eating a low-salt diet [211]. Near-daily aerobic activity that increases heart rate, breathing, and sweating for at least $20 \mathrm{~min}$, such as playing basketball, is correlated with reduced frequency, severity, and symptomology of upper respiratory tract infections [212]. Of relevance, no professional basketball players tested positive for COVID-19 during the first five weeks of the 2020 National Basketball Association playoffs during the pandemic [213], which may be related to the athletes' profuse sweating of up to more than four liters during each game [214]. In addition, Artic warming is linked to the increased frequency of extreme winter conditions in the Eastern United States [215], which could intensify or extend behavioral patterns of higher sodium chloride intake during cold weather, thus contributing to the frequency of severe ILIs associated with sodium toxicity.

Salt, fat, and sugar added to highly processed foods also contribute unhealthy commodities that increase the risks associated with non-communicable disease pandemics affecting low-income and middle-income countries [216,217]. However, the potential of sodium chloride in processed foods to cause pandemics of infectious diseases is underinvestigated. Even felines in zoos are fed processed canned foods containing added sodium chloride [218], and SARS-CoV-2 infection has been detected within these animals [219].

During World War I, before modern food preservatives or commercial frozen foods were available, sodium chloride was the preservative of choice in canned foods, which were just coming onto the market [220]. Canned foods replaced fresh foods that were rationed during the war and were no longer available to the general public [221]. The 1918 influenza pandemic, which killed an estimated 20-50 million people, began in March as a typical seasonal influenza and weakened over the summer. A second wave returned in the fall when it increased in virulence, with reports describing "blistering fevers" and how "patients would drown in their own fluid-filled lungs" [222]. With so many deaths, "many questioned whether such an explosively fatal disease could be influenza at all" [223]. "War edema" during WWI was linked to European populations consuming "large amounts of fluid and salt in the attempt to sustain life on the thin vegetable soups common in prison camps and in famine districts" [224].

Doctors from the U.S. Navy in Boston, Massachusetts, in 1918 exposed 62 healthy male sailors to a variety of direct contact with the sputum, coughs, and exhaled breath from severely ill influenza patients [225]. Although one healthy sailor developed a sore throat, none of the healthy sailors became ill with confirmed cases of influenza. A similar experiment was later repeated in San Francisco, California, and the results were negative, providing strong evidence that the influenza virus was noninfectious. More recent literature reviews found scant or no evidence of influenza or SARS-CoV-2 transmission in controlled experiments involving asymptomatic and presymptomatic patients [226,227], providing further supporting evidence that RNA viruses in ILIs are noninfectious. These clinical findings challenge conventional views claiming that influenza infections spread through droplets containing individual viruses [228]. Furthermore, "increasing evidence indicates that viruses do not simply propagate as independent virions among cells, organs, and host" [229], and individual virions rarely establish infections [42]. Rather, large aggregates of virions within the body are required to overcome immune barriers and mediate viral infection [37]. 
After World War I ended and fresh foods were no longer rationed, the influenza pandemic eventually subsided in 1919. Of note, placing patients directly in the warm sun all day was part of an effective open-air treatment for influenza during the 1918 pandemic [230], which is consistent with previously cited sodium losses through the skin in moderately hot conditions. Furthermore, an early controlled trial found that sauna bathing decreased the frequency of the common cold [231], and saunas were also associated with decreased incidence of hypertension in a prospective cohort study in Finland [232], which could be related to sodium losses through sweating.

Sea voyages extending back many centuries were notorious for high mortality rates among ship crew and passengers, and onboard food provisions were often highly salted [233]. "Mariners recognized a connection between their diets and their health", and fresh fruits and vegetables were acknowledged to cure "scorbutic disorders which are contracted by salt diet and long voyages" [234]. In 1915, many crew members of the German ship SS Kronprinz Wilhelm suffered debilitating malnutrition, with edema, shortness of breath, and pneumonia, on a diet high in salted meat and processed foods [235]. Even when carrying more fresh fruit and vegetables, modern cruise ships appear susceptible to infectious disease outbreaks, evidenced by the coronavirus outbreak aboard the cruise ship Diamond Princess [236]. The procurement of food on board liner ships should avoid over reliance on processed foods in response to supply chain challenges of food degradation and "shelf life constraints for raw materials and perishable products" [237].

Today's high cost and restricted availability of fresh unprocessed nutrient-rich foods like whole fruits and vegetables, compared with less expensive and highly-salted processed foods, could account for increased COVID-19 infections within lower socioeconomic communities [238]. A recent systematic review and meta-analysis of studies investigating healthy adult populations found that people of lower socioeconomic status consume $14 \%$ more sodium than people of a higher socioeconomic status [239]. Southwestern American Indians in particular had the highest mortality rates of all racial-ethnic groups in the 1918 influenza pandemic and the $2009 \mathrm{H} 1 \mathrm{~N} 1$ pandemic, and have had exceedingly high hospitalization rates, younger patients, and disease severity in the COVID-19 pandemic [240]. The Southwestern American Indian population also has disproportionally high rates of mortality from diabetes, obesity, and cardiovascular disease, and the population's "inadequate access to healthy foods" [240] suggests a potential link to sodium toxicity.

Furthermore, seasonal influenza outbreaks in long-term care facilities are "well recognized" [241], as occurred during the COVID-19 pandemic [242]. Nursing homes have been associated with inconsistent climate control conditions [243], and COVID-19 outbreaks in prisons are attributed to overcrowding [244]. Inferior institutional food service is also common in government-run nursing homes and prisons [245].

"Our taxpayer-funded, government-run institutions focus on meeting legal nutritional guidelines for the lowest price ... Many people facing illness or incarceration are without options or a voice. They are reduced to eating the most processed, least nutritious food available, entirely because it's cheapest for the rest of us" [245].

Even people living at home who avoid public markets during a pandemic may face nutritional challenges from a "greater consumption of processed, nonperishable foods which can be high in sodium" [4]. These findings imply a need for government subsidies to lower consumer prices of fresh, unprocessed whole foods, and increase the availability of these foods to vulnerable populations. Along with nutritional education, such a national nutritional policy would greatly benefit public health and help prevent noncommunicable diseases, as well as potentially prevent infectious diseases throughout the nation. Furthermore, interventions to reduce COVID-19 morbidity and mortality through reduced-sodium diets should be explored, particularly targeting long-term care homes with vulnerable populations. 


\section{Conclusions}

This perspective article used a grounded theory method to synthesize evidence from virology, immunology, pathophysiology, and epidemiology literature, inferring that sodium toxicity is a modifiable factor potentially associated with COVID-19 morbidity and mortality. A high sodium chloride intake is a risk factor associated with diseases that are also risk factors of underlying conditions associated with COVID-19 morbidity and mortality. The most fatal pathological effect of COVID-19 is acute respiratory distress syndrome with yellow fluid that blocks lung air sacs, and this appears to be the same fluid in pulmonary edema caused by excess sodium chloride. Sodium toxicity is also associated with other symptoms of COVID-19 like fever and nasal sinus congestion. Virion aggregates form from undisposed cellular waste, and most virion aggregates in influenza A contain noninfectious viruses. Similar aggregates of SARS-CoV-2 may accumulate in the upper nasal passages due to impaired mucociliary clearance from the ciliostasis-effect of sodium chloride. Sodium toxicity in highly processed foods also potentially contributes to infectious influenza-like illnesses, and further exploration of low-sodium diets to reduce COVID-19 morbidity and mortality are needed.

The limitations of this paper include the nascent literature on COVID-19, which, although plentiful, has not been sufficiently investigated to generate great depth, maturity, and diversity of knowledge. In addition, as with any theory, the concepts described in this paper are subject to verification through hypothesis testing, and the need to modify theoretical concepts is likely to occur as more evidence accumulates. The transdisciplinary nature of the paper also draws upon a broad range of knowledge domains, and is not intended as a substitute for more advanced papers in these areas. Finally, although the grounded theory method attempts to minimize subjectivity, each researcher has a unique point of view, and similar papers on this topic by other authors are needed to contribute diverse perspectives.

Funding: This research received no external funding.

Institutional Review Board Statement: Not applicable.

Informed Consent Statement: Not applicable.

Data Availability Statement: Not applicable.

Conflicts of Interest: The author declares no conflict of interest.

\section{References}

1. Cucinotta, D.; Vanelli, M. WHO Declares COVID-19 a Pandemic. Acta Bio-Med. Atenei Parm. 2020, 91, 157.

2. Thigpen, C.L.; Funk, C. Most Americans Expect a COVID-19 Vaccine within a Year: 72\% Say they would get vaccinated. Available online: https:/ / www.pewresearch.org/fact-tank/2020/05/21/most-americans-expect-a-covid-19-vaccine-within-a-year-72 -say-they-would-get-vaccinated/ (accessed on 21 May 2020).

3. Glasziou, P.P.; Sanders, S.; Hoffmann, T. Waste in covid-19 research. BMJ 2020, 369, m1847. [CrossRef]

4. Schrack, J.A.; Wanigatunga, A.A.; Juraschek, S.P. After the COVID-19 Pandemic: The Next Wave of Health Challenges for Older Adults. J. Gerontol. Ser. A 2020. [CrossRef] [PubMed]

5. WHO. WHO Surveillance Case Definitions for ILI and SARI. Available online: https://www.who.int/influenza/surveillance_ monitoring/ili_sari_surveillance_case_definition/en/ (accessed on 26 April 2020).

6. Koene, R.J.; Prizment, A.E.; Blaes, A.; Konety, S.H. Shared risk factors in cardiovascular disease and cancer. Circulation 2016, 133, 1104-1114. [CrossRef] [PubMed]

7. Mozaffarian, D.; Rosenberg, I.; Uauy, R. History of modern nutrition science-Implications for current research, dietary guidelines, and food policy. BMJ 2018, 361, k2392. [CrossRef] [PubMed]

8. Kupiec, T.C.; Goldenring, J.M.; Raj, V. A non-fatal case of sodium toxicity. J. Anal. Toxicol. 2004, 28, 526-528. [CrossRef]

9. Metheny, N.A.; Krieger, M.M. Salt Toxicity: A Systematic Review and Case Reports. J. Emerg. Nurs. 2020, 46, 428-439. [CrossRef]

10. Afshin, A.; Sur, P.J.; Fay, K.A.; Cornaby, L.; Ferrara, G.; Salama, J.S.; Mullany, E.C.; Abate, K.H.; Abbafati, C.; Abebe, Z. Health effects of dietary risks in 195 countries, 1990-2017: A systematic analysis for the Global Burden of Disease Study 2017. Lancet 2019, 393, 1958-1972. [CrossRef]

11. Zabetakis, I.; Lordan, R.; Norton, C.; Tsoupras, A. COVID-19: The Inflammation Link and the Role of Nutrition in Potential Mitigation. Nutrients 2020, 12, 1466. [CrossRef] 
12. Sun, J.; de Vos, P. Immunomodulatory functions of nutritional ingredients in health and disease. Front. Immunol. 2019, 10, 50. [CrossRef]

13. WHO. Infections and Infectious Diseases: A Manual for Nurses and Midwives in the WHO European Region. Available online: https://www.euro.who.int/_data/assets/pdf_file/0013/102316/e79822.pdf (accessed on 5 October 2020).

14. Esser, C.; Hochrath, K.; Schikowski, T.; Haarmann-Stemmann, T. COVID-19 research: Toxicological input urgently needed! Arch. Toxicol. 2020. [CrossRef]

15. Wolfswinkel, J.F.; Furtmueller, E.; Wilderom, C.P.M. Using grounded theory as a method for rigorously reviewing literature. Eur. J. Inf. Syst. 2013, 22, 45-55. [CrossRef]

16. Brown, R.B. Breakthrough knowledge synthesis in the Age of Google. Philosophies 2020, 5, 4. [CrossRef]

17. Lodish, H.; Berk, A.; Zipursky, S.L.; Matsudaira, P.; Baltimore, D.; Darnell, J. Viruses: Structure, function, and uses. In Molecular Cell Biology, 4th ed.; WH Freeman: New York, NY, USA, 2000.

18. Zou, S.; Caler, L.; Colombini-Hatch, S.; Glynn, S.; Srinivas, P. Research on the Human Virome: Where are We and What Is Next; Springer: Berlin/Heidelberg, Germany, 2016. [CrossRef]

19. Delwart, E. Viruses of the Human Body: Some of Our Resident Viruses may be Beneficial. Available online: https://www.thescientist.com/features/viruses-of-the-human-body-32614 (accessed on 25 May 2020).

20. Kim, D.; Lee, J.-Y.; Yang, J.-S.; Kim, J.W.; Kim, V.N.; Chang, H. The architecture of SARS-CoV-2 transcriptome. Cell 2020, 181, 914-921. [CrossRef] [PubMed]

21. Shokolenko, I.N.; Alexeyev, M.F. Mitochondrial DNA: A disposable genome? Biochim. Biophys. Acta Mol. Basis Dis. 2015, 1852, 1805-1809. [CrossRef]

22. Bogenhagen, D.F. Mitochondrial DNA nucleoid structure. Biochim. Biophys. Acta Gene Regul. Mech. 2012, 1819, 914-920. [CrossRef] [PubMed]

23. Cole, L.W. The evolution of per-cell organelle number. Front. Cell Dev. Biol. 2016, 4, 85. [CrossRef] [PubMed]

24. Griswold, A. Genome packaging in prokaryotes: The circular chromosome of E. coli. Nat. Educ. 2008, 1, 57.

25. Dance, A. How Cells Take out the Trash. Available online: https://www.nigms.nih.gov/education/Inside-Life-Science/Pages/ How-Cells-Take-Out-the-Trash.aspx (accessed on 27 May 2020).

26. Gerba, C.P.; Betancourt, W.Q. Viral aggregation: Impact on virus behavior in the environment. Environ. Sci. Technol. 2017, 51, 7318-7325. [CrossRef]

27. Yuana, Y.; Sturk, A.; Nieuwland, R. Extracellular vesicles in physiological and pathological conditions. Blood Rev. 2013, 27, 31-39. [CrossRef]

28. Nolte, E.; Cremer, T.; Gallo, R.C.; Margolis, L.B. Extracellular vesicles and viruses: Are they close relatives? Proc. Natl. Acad. Sci. USA 2016, 113, 9155-9161. [CrossRef]

29. Cobb, M. Who discovered messenger RNA? Curr. Biol. 2015, 25, R526-R532. [CrossRef]

30. Shyu, A.B.; Wilkinson, M.F.; Van Hoof, A. Messenger RNA regulation: To translate or to degrade. EMBO J. 2008, $27,471-481$. [CrossRef] [PubMed]

31. Barchiesi, A.; Vascotto, C. Transcription, processing, and decay of mitochondrial RNA in health and disease. Int. J. Mol. Sci. 2019, 20, 2221. [CrossRef] [PubMed]

32. Batagov, A.O.; Kurochkin, I.V. Exosomes secreted by human cells transport largely mRNA fragments that are enriched in the 3'-untranslated regions. Biol. Direct 2013, 8, 12. [CrossRef]

33. Fenner, F.J.; White, D.O. Chapter 2-Virus Replication. In Fenner's Veterinary Virology, 4th ed.; MacLachlan, N.J., Dubovi, E.J., Eds.; Academic Press: San Diego, CA, USA, 2011. [CrossRef]

34. Brooke, C.B. Biological activities of 'noninfectious' influenza A virus particles. Future Virol. 2014, 9, 41-51. [CrossRef] [PubMed]

35. Joynt, G.M.; Wu, W.K. Understanding COVID-19: What does viral RNA load really mean? Lancet Infect. Dis. 2020, 20, 635-636. [CrossRef]

36. Sansone, P.; Savini, C.; Kurelac, I.; Chang, Q.; Amato, L.B.; Strillacci, A.; Stepanova, A.; Iommarini, L.; Mastroleo, C.; Daly, L. Packaging and transfer of mitochondrial DNA via exosomes regulate escape from dormancy in hormonal therapy-resistant breast cancer. Proc. Natl. Acad. Sci. USA 2017, 114, E9066-E9075. [CrossRef]

37. Andreu-Moreno, I.; Sanjuán, R. Collective Viral Spread Mediated by Virion Aggregates Promotes the Evolution of Defective Interfering Particles. MBio 2020, 11, e02156-19. [CrossRef]

38. Spriggs, C.C.; Harwood, M.C.; Tsai, B. How non-enveloped viruses hijack host machineries to cause infection. Adv. Virus Res. 2019, 104, 97-122. [CrossRef] [PubMed]

39. Katsnelson, A. What do We Know about the Novel Coronavirus's 29 proteins? Available online: https://cen.acs.org/biologicalchemistry/infectious-disease/know-novel-coronaviruss-29-proteins/98/web/2020/04 (accessed on 12 July 2020).

40. Atkinson, B.; Petersen, E. SARS-CoV-2 shedding and infectivity. Lancet 2020, 395, 1339-1340. [CrossRef]

41. Noda, T.; Kawaoka, Y. Packaging of influenza virus genome: Robustness of selection. Proc. Natl. Acad. Sci. USA 2012, 109, 8797-8798. [CrossRef]

42. Sanjuán, R.; Thoulouze, M.-I. Why viruses sometimes disperse in groups. Virus Evol. 2019, 5, vez014. [CrossRef] [PubMed]

43. Iba, T.; Ogura, H. Role of extracellular vesicles in the development of sepsis-induced coagulopathy. J. Intensive Care 2018, 6, 68. [CrossRef] [PubMed] 
44. Li, H.; Liu, L.; Zhang, D.; Xu, J.; Dai, H.; Tang, N.; Su, X.; Cao, B. SARS-CoV-2 and viral sepsis: Observations and hypotheses. Lancet 2020, 395, 1517-1520. [CrossRef]

45. Lin, G.-L.; McGinley, J.P.; Drysdale, S.B.; Pollard, A.J. Epidemiology and immune pathogenesis of viral sepsis. Front. Immunol. 2018, 9, 2147. [CrossRef]

46. oie.int. Questions and Answers on COVID-19. Available online: https://www.oie.int/en/scientific-expertise/specificinformation-and-recommendations / questions-and-answers-on-2019novel-coronavirus / (accessed on 1 July 2020).

47. Pan, L.; Mu, M.; Ren, H. Clinical characteristics of COVID-19 patients with digestive symptoms in Hubei, China: A descriptive, cross-sectional, multicenter study. Am. J. Gastroenterol. 2020. [CrossRef]

48. Rothan, H.A.; Byrareddy, S.N. The epidemiology and pathogenesis of coronavirus disease (COVID-19) outbreak. J. Autoimmun. 2020, 109, 102433. [CrossRef]

49. Kurpiers, L.A.; Schulte-Herbrüggen, B.; Ejotre, I.; Reeder, D.M. Bushmeat and emerging infectious diseases: Lessons from Africa. In Problematic Wildlife; Springer: Cham, Switzerland, 2016; pp. 507-551.

50. Hu, B.; Zeng, L.-P.; Yang, X.-L.; Ge, X.-Y.; Zhang, W.; Li, B.; Xie, J.-Z.; Shen, X.-R.; Zhang, Y.-Z.; Wang, N. Discovery of a rich gene pool of bat SARS-related coronaviruses provides new insights into the origin of SARS coronavirus. PLoS Pathog. 2017, 13, e1006698. [CrossRef]

51. Peng, A.W.; Juraschek, S.P.; Appel, L.J.; Miller, E.R.I.; Mueller, N.T. Effects of the DASH Diet and Sodium Intake on Bloating: Results From the DASH-Sodium Trial. Off. J. Am. Coll. Gastroenterol. 2019, 114, 1109-1115. [CrossRef]

52. Moore, P.S. Pathogens and disease: Issues in determining causality. In The Infectious Etiology of Chronic Diseases: Defining the Relationship, Enhancing the Research, and Mitigating the Effects: Workshop Summary; National Academies Press: Washington, DC, USA, 2004; p. 140.

53. WHO. "Immunity Passports" in the Context of COVID-19. Available online: https://www.who.int/news-room/commentaries/ detail/immunity-passports-in-the-context-of-covid-19 (accessed on 26 April 2020).

54. Cook, D.J.; Marshall, J.C.; Fowler, R.A. Critical Illness in Patients With COVID-19: Mounting an Effective Clinical and Research Response. JAMA 2020, 323, 1559-1560. [CrossRef]

55. Barakat, A.; Ihazmad, H.; El Falaki, F.; Tempia, S.; Cherkaoui, I.; El Aouad, R. 2009 Pandemic influenza A virus subtype H1N1 in Morocco, 2009-2010: Epidemiology, transmissibility, and factors associated with fatal cases. J. Infect. Dis. 2012, 206, S94-S100. [CrossRef] [PubMed]

56. Ji, H.; Gu, Q.; Chen, L.-L.; Xu, K.; Ling, X.; Bao, C.-J.; Tang, F.-Y.; Qi, X.; Wu, Y.-Q.; Ai, J. Epidemiological and clinical characteristics and risk factors for death of patients with avian influenza A H7N9 virus infection from Jiangsu Province, Eastern China. PLoS ONE 2014, 9, e89581. [CrossRef] [PubMed]

57. Grillo, A.; Salvi, L.; Coruzzi, P.; Salvi, P.; Parati, G. Sodium intake and hypertension. Nutrients 2019, 11, 1970. [CrossRef] [PubMed]

58. Tan, M.; He, F.J.; Wang, C.; MacGregor, G.A. Twenty-Four-Hour Urinary Sodium and Potassium Excretion in China: A Systematic Review and Meta-Analysis. J. Am. Heart Assoc. 2019, 8, e012923. [CrossRef]

59. Lu, J.; Lu, Y.; Wang, X.; Li, X.; Linderman, G.C.; Wu, C.; Cheng, X.; Mu, L.; Zhang, H.; Liu, J. Prevalence, awareness, treatment, and control of hypertension in China: Data from 1. 7 million adults in a population-based screening study (China PEACE Million Persons Project). Lancet 2017, 390, 2549-2558. [CrossRef]

60. Donfrancesco, C.; Lo Noce, C.; Russo, O.; Minutoli, D.; Di Lonardo, A.; Buttari, B.; Profumo, E.; Galeone, D.; Giampaoli, S.; Bellisario, P. Abstract P352: Trend of Salt Consumption in Italy from 2008 to 2018: Preliminary Results of the Cuore Project. Circulation 2020, 141, AP352. [CrossRef]

61. Torlasco, C.; Faini, A.; Makil, E.; Bilo, G.; Pengo, M.; Beaney, T.; Xia, X.; Borghi, C.; Poulter, N.R.; Tocci, G. Nation-wide hypertension screening in Italy: Data from May Measurements Month 2017-Europe. Eur. Heart J. Suppl. 2019, 21, D66-D70. [CrossRef]

62. Onder, G.; Rezza, G.; Brusaferro, S. Case-fatality rate and characteristics of patients dying in relation to COVID-19 in Italy. JAMA 2020, 323, 1775-1776. [CrossRef]

63. Thout, S.R.; Santos, J.A.; McKenzie, B.; Trieu, K.; Johnson, C.; McLean, R.; Arcand, J.; Campbell, N.R.; Webster, J. The Science of Salt: Updating the evidence on global estimates of salt intake. J. Clin. Hypertens. 2019, 21, 710-721. [CrossRef]

64. Mao, L.; Jin, H.; Wang, M.; Hu, Y.; Chen, S.; He, Q.; Chang, J.; Hong, C.; Zhou, Y.; Wang, D. Neurologic Manifestations of Hospitalized Patients with Coronavirus Disease 2019 in Wuhan, China. JAMA Neurol. 2020, 77, 683-690. [CrossRef]

65. Magro, C.; Mulvey, J.J.; Berlin, D.; Nuovo, G.; Salvatore, S.; Harp, J.; Baxter-Stoltzfus, A.; Laurence, J. Complement associated microvascular injury and thrombosis in the pathogenesis of severe COVID-19 infection: A report of five cases. Transl. Res. 2020, 220, 1-13. [CrossRef] [PubMed]

66. Bhatla, A.; Mayer, M.M.; Adusumalli, S.; Hyman, M.C.; Oh, E.; Tierney, A.; Moss, J.; Chahal, A.A.; Anesi, G.; Denduluri, S. COVID-19 and Cardiac Arrhythmias. Heart Rhythm 2020, 17, 1439-1444. [CrossRef]

67. Madjid, M.; Safavi-Naeini, P.; Solomon, S.D.; Vardeny, O. Potential effects of coronaviruses on the cardiovascular system: A review. JAMA Cardiol. 2020, 5, 831-840. [CrossRef]

68. Lighter, J.; Phillips, M.; Hochman, S.; Sterling, S.; Johnson, D.; Francois, F.; Stachel, A. Obesity in patients younger than 60 years is a risk factor for Covid-19 hospital admission. Clin. Infect. Dis. 2020, 71, 896-897. [CrossRef] [PubMed]

69. Rubino, F.; Amiel, S.A.; Zimmet, P.; Alberti, G.; Bornstein, S.; Eckel, R.H.; Mingrone, G.; Boehm, B.; Cooper, M.E.; Chai, Z. New-Onset Diabetes in Covid-19. New Engl. J. Med. 2020, 383, 789-790. [CrossRef] [PubMed] 
70. Cheng, Y.; Luo, R.; Wang, K.; Zhang, M.; Wang, Z.; Dong, L.; Li, J.; Yao, Y.; Ge, S.; Xu, G. Kidney disease is associated with in-hospital death of patients with COVID-19. Kidney Int. 2020, 97, 829-838. [CrossRef] [PubMed]

71. Wu, J.; Song, S.; Cao, H.-C.; Li, L.-J. Liver diseases in COVID-19: Etiology, treatment and prognosis. World J. Gastroenterol. 2020, 26, 2286. [CrossRef]

72. Salter, A.; Fox, R.J.; Newsome, S.D.; Halper, J.; Li, D.K.; Kanellis, P.; Costello, K.; Bebo, B.; Rammohan, K.; Cutter, G.R. Outcomes and risk factors associated with SARS-CoV-2 Infection in a North American registry of patients with multiple sclerosis. JAMA Neurol. 2021, 78, 699-708. [CrossRef]

73. Denton, C.P.; Campochiaro, C.; Bruni, C.; Distler, O.; Iagnocco, A.; Matucci Cerinic, M. COVID-19 and systemic sclerosis: Rising to the challenge of a pandemic. J. Scleroderma Relat. Disord. 2020, 6, 58-65. [CrossRef]

74. Sampaio Rocha-Filho, P.A.; Magalhães, J.E. Headache associated with COVID-19: Frequency, characteristics and association with anosmia and ageusia. Cephalalgia 2020, 40, 1443-1451. [CrossRef]

75. Almufarrij, I.; Munro, K.J. One year on: An updated systematic review of SARS-CoV-2, COVID-19 and audio-vestibular symptoms. Int. J. Audiol. 2021, 1-11. [CrossRef] [PubMed]

76. Lima, M.A.; Silva, M.T.T.; Soares, C.N.; Coutinho, R.; Oliveira, H.S.; Afonso, L.; Espíndola, O.; Leite, A.C.; Araujo, A. Peripheral facial nerve palsy associated with COVID-19. J. Neurovirol. 2020, 26, 941-944. [CrossRef] [PubMed]

77. Subramanian, A.; Anand, A.; Adderley, N.J.; Okoth, K.; Toulis, K.A.; Gokhale, K.; Sainsbury, C.; O’Reilly, M.W.; Arlt, W.; Nirantharakumar, K. Increased COVID-19 infections in women with polycystic ovary syndrome: A population-based study. Eur. J. Endocrinol. 2021, 184, 637-645. [CrossRef] [PubMed]

78. Wang, D.; Hu, B.; Hu, C.; Zhu, F.; Liu, X.; Zhang, J.; Wang, B.; Xiang, H.; Cheng, Z.; Xiong, Y. Clinical characteristics of 138 hospitalized patients with 2019 novel coronavirus-infected pneumonia in Wuhan, China. JAMA 2020, 323, 1061-1069. [CrossRef] [PubMed]

79. Li, Q. An outbreak of NCIP (2019-nCoV) infection in China-Wuhan, Hubei province, 2019-2020. China CDC Wkly. 2020, 2, 79-80. [CrossRef]

80. Schmidt-Pogoda, A.; Strecker, J.-K.; Liebmann, M.; Massoth, C.; Beuker, C.; Hansen, U.; König, S.; Albrecht, S.; Bock, S.; Breuer, J. Dietary salt promotes ischemic brain injury and is associated with parenchymal migrasome formation. PLoS ONE 2018, 13, e0209871. [CrossRef]

81. Dmitrieva, N.I.; Burg, M.B. Secretion of von Willebrand factor by endothelial cells links sodium to hypercoagulability and thrombosis. Proc. Natl. Acad. Sci. USA 2014, 111, 6485-6490. [CrossRef]

82. Pääkkö, T.J.W.; Perkiömäki, J.S.; Silaste, M.-L.; Bloigu, R.; Huikuri, H.V.; Antero Kesäniemi, Y.; Ukkola, O.H. Dietary sodium intake is associated with long-term risk of new-onset atrial fibrillation. Ann. Med. 2018, 50, 694-703. [CrossRef]

83. He, M.; Mu, J.; Liu, F.; Ren, K.; Wang, Y.; Guo, T.; Wang, D. Effects of a high salt intake and potassium supplementation on QT interval dispersion in normotensive healthy subjects. Intern. Med. 2015, 54, 295-301. [CrossRef]

84. Zhou, L.; Stamler, J.; Chan, Q.; Van Horn, L.; Daviglus, M.L.; Dyer, A.R.; Miura, K.; Okuda, N.; Wu, Y.; Ueshima, H. Salt intake and prevalence of overweight/obesity in Japan, China, the United Kingdom, and the United States: The INTERMAP Study. Am. J. Clin. Nutr. 2019, 110, 34-40. [CrossRef]

85. ScienceDaily.com. Sodium (Salt) Intake is Associated with a Risk of Developing Type 2 Diabetes. Available online: https: / / www.sciencedaily.com/releases/2017/09/170914210621.htm (accessed on 20 July 2020).

86. Maruta, Y.; Hasegawa, T.; Yamakoshi, E.; Nishiwaki, H.; Koiwa, F.; Imai, E.; Hishida, A. Association between serum Na-Cl level and renal function decline in chronic kidney disease: Results from the chronic kidney disease Japan cohort (CKD-JAC) study. Clin. Exp. Nephrol. 2019, 23, 215-222. [CrossRef]

87. Wang, G.; Yeung, C.-K.; Wong, W.-Y.; Zhang, N.; Wei, Y.-F.; Zhang, J.-L.; Yan, Y.; Wong, C.-Y.; Tang, J.-J.; Chuai, M. Liver fibrosis can be induced by high salt intake through excess reactive oxygen species (ROS) production. J. Agric. Food Chem. 2016, 64, 1610-1617. [CrossRef]

88. Zostawa, J.; Adamczyk, J.; Sowa, P.; Adamczyk-Sowa, M. The influence of sodium on pathophysiology of multiple sclerosis. Neurol. Sci. 2017, 38, 389-398. [CrossRef]

89. Kopp, C.; Beyer, C.; Linz, P.; Dahlmann, A.; Hammon, M.; Jantsch, J.; Neubert, P.; Rosenhauer, D.; Müller, D.N.; Cavallaro, A. Na+ deposition in the fibrotic skin of systemic sclerosis patients detected by 23Na-magnetic resonance imaging. Rheumatology 2017, 56, 556-560. [CrossRef]

90. Ghaffari, H.; Grant, S.C.; Petzold, L.R.; Harrington, M.G. Regulation of CSF and brain tissue sodium levels by the blood-CSF and blood-brain barriers during migraine. Front. Comput. Neurosci. 2020, 14, 4. [CrossRef]

91. Henry, J.A.; Zaugg, T.L.; Myers, P.J.; Kendall, C.J.; Michaelides, E.M. A triage guide for tinnitus. J. Fam. Pract. $2010,59,389$.

92. Sardana, D.; Bahadur, S. Effect of compression in the etiology of experimental Bell's palsy. Indian J. Otolaryngol. Head Neck Surg. $1979,31,61$.

93. Shishehgar, F.; Ramezani Tehrani, F.; Mirmiran, P.; Hajian, S.; Baghestani, A.R.; Moslehi, N. Comparison of Dietary Intake between Polycystic Ovary Syndrome Women and Controls. Glob. J. Health Sci. 2016, 8, 54801. [CrossRef]

94. Wilder, T.; Drake, T. Metabolism of chloride and total fixed base in pneumonia and the relation to salt and water retention. J. Clin. Investig. 1929, 7, 353-364. [CrossRef]

95. cdc.gov. Multisystem Inflammatory Syndrome in Children (MIS-C) Associated with Coronavirus Disease 2019 (COVID-19). Available online: https:/ / emergency.cdc.gov/han/2020/han00432.asp (accessed on 30 May 2020). 
96. Sayyahfar, S.; Hoseini, R. Kawasaki Disease and Hypertension in an Infant. Arch. Pediatric Infect. Dis. 2017, 5. [CrossRef]

97. Prangwatanagul, W.; Limsuwan, A. Ischemic stroke in Kawasaki disease. Pediatrics Int. 2017, 59, 92-96. [CrossRef]

98. Belhadjer, Z.; Méot, M.; Bajolle, F.; Khraiche, D.; Legendre, A.; Abakka, S.; Auriau, J.; Grimaud, M.; Oualha, M.; Beghetti, M. Acute heart failure in multisystem inflammatory syndrome in children (MIS-C) in the context of global SARS-CoV-2 pandemic. Circulation 2020, 142, 429-436. [CrossRef] [PubMed]

99. Chuang, G.-T.; Tsai, I.-J.; Lin, M.-T.; Chang, L.-Y. Acute kidney injury in patients with Kawasaki disease. Pediatric Res. 2016, 80, 224-227. [CrossRef]

100. NHLBI. Implementing Recommendations for Dietary Salt Reduction: Where Are We? Where Are We Going? How Do We Get There? A Summary of an NHLBI Workshop; National Institutes of Health, National Heart, Lung, and Blood Institute: Bethesda, MD, USA, 1996.

101. hsph.harvard.edu. Salt and Sodium. Available online: https://www.hsph.harvard.edu/nutritionsource/salt-and-sodium/ (accessed on 4 June 2020).

102. Bommaraju, T.V.; Orosz, P.J.; Sokol, E.A. Brine Electrolysis. Available online: https://knowledge.electrochem.org/encycl/art-b0 1-brine.htm (accessed on 6 June 2020).

103. Roux, B. Ion channels and ion selectivity. Essays Biochem. 2017, 61, 201-209. [CrossRef]

104. sciencemediacentre.org. Expert Reaction to Study Looking at Salt Consumption and Health Risks. Available online: https: / / www.sciencemediacentre.org/expert-reaction-to-study-looking-at-salt-consumption-and-health-risks/ (accessed on 4 June 2020).

105. Johnston, I. Lancet Attacked for Publishing Study Claiming Low-Salt Diet Could Kill You. Available online: https://www. independent.co.uk/news/science/salt-diet-heart-disease-death-lancet-a7040546.html (accessed on 4 June 2020).

106. Yeates, K.E.; Singer, M.; Morton, A.R. Salt and water: A simple approach to hyponatremia. CMAJ 2004, 170, 365-369.

107. Fortune, B.E.; Garcia-Tsao, G. Hypervolemic hyponatremia: Clinical significance and management. Clin. Liver Dis. 2013, 2, 109. [CrossRef]

108. Braun, M.M.; Barstow, C.; Pyzocha, N. Diagnosis and management of sodium disorders: Hyponatremia and hypernatremia. Am. Fam. Physician 2015, 91, 299-307. [PubMed]

109. Frontera, J.A.; Valdes, E.; Huang, J.; Lewis, A.; Lord, A.S.; Zhou, T.; Kahn, D.E.; Melmed, K.; Czeisler, B.M.; Yaghi, S. Prevalence and impact of hyponatremia in patients with coronavirus disease 2019 in New York City. Crit. Care Med. 2020. [CrossRef] [PubMed]

110. Tezcan, M.E.; Gokce, G.D.; Sen, N.; Kaymak, N.Z.; Ozer, R. Baseline electrolyte abnormalities would be related to poor prognosis in hospitalized coronavirus disease 2019 patients. N. Microbes N. Infect. 2020, 37, 100753. [CrossRef]

111. Torres-Macho, J.; Ryan, P.; Valencia, J.; Pérez-Butragueño, M.; Jiménez, E.; Fontán-Vela, M.; Izquierdo-García, E.; FernandezJimenez, I.; Álvaro-Alonso, E.; Lazaro, A. The PANDEMYC Score. An Easily Applicable and Interpretable Model for Predicting Mortality Associated with COVID-19. J. Clin. Med. 2020, 9, 3066. [CrossRef]

112. Berni, A.; Malandrino, D.; Parenti, G.; Maggi, M.; Poggesi, L.; Peri, A. Hyponatremia, IL-6, and SARS-CoV-2 (COVID-19) infection: May all fit together? J. Endocrinol. Investig. 2020, 43, 1137-1139. [CrossRef]

113. Corona, G.; Giuliani, C.; Parenti, G.; Norello, D.; Verbalis, J.G.; Forti, G.; Maggi, M.; Peri, A. Moderate hyponatremia is associated with increased risk of mortality: Evidence from a meta-analysis. PLoS ONE 2013, 8, e80451. [CrossRef]

114. Christ-Crain, M.; Hoorn, E.J.; Sherlock, M.; Thompson, C.J.; Wass, J.A. Endocrinology in the time of COVID-19: Management of diabetes insipidus and hyponatraemia. Eur. J. Endocrinol. 2020, 183, G9-G15. [CrossRef]

115. Hu, W.; Li, C.; Xu, Y.; Qi, Y.; Zhang, Z.; Li, M.; Cai, F.; Liu, D.; Yue, J.; Ye, M. Disorders of sodium balance and its clinical implications in COVID-19 patients: A multicenter retrospective study. Intern. Emerg. Med. 2021, 16, 853-862. [CrossRef]

116. Post, A.; Dullaart, R.P.; Bakker, S.J. Sodium status and kidney involvement during COVID-19 infection. Virus Res. 2020, 286, 198034. [CrossRef]

117. Post, A.; Dullaart, R.P.; Bakker, S.J. Is low sodium intake a risk factor for severe and fatal COVID-19 infection? Eur. J. Intern. Med. 2020, 75, 109. [CrossRef]

118. Lippi, G.; South, A.M.; Henry, B.M. Electrolyte imbalances in patients with severe coronavirus disease 2019 (COVID-19). Ann. Clin. Biochem. 2020, 57, 262-265. [CrossRef]

119. Królicka, A.L.; Kruczkowska, A.; Krajewska, M.; Kusztal, M.A. Hyponatremia in Infectious Diseases-A Literature Review. Int. J. Environ. Res. Public Health 2020, 17, 5320. [CrossRef]

120. Yang, M.-W.; Chen, F.; Zhu, D.-J.; Li, J.-Z.; Zhu, J.-L.; Zeng, W.; Qu, S.-L.; Zhang, Y. Clinical efficacy of Matrine and Sodium Chloride Injection in treatment of 40 cases of COVID-19. Zhongguo Zhong Yao Za Zhi. 2020, 45, 2221-2231.

121. Thomas, C.P.; Batuman, V. Syndrome of Inappropriate Antidiuretic Hormone Secretion. Available online: https://emedicine. medscape.com/article/246650-overview (accessed on 22 June 2021).

122. Sugiura, T.; Takase, H.; Ohte, N.; Dohi, Y. Dietary salt intake is a significant determinant of impaired kidney function in the general population. Kidney Blood Press. Res. 2018, 43, 1245-1254. [CrossRef]

123. Oppelaar, J.J.; Vogt, L. Body Fluid-Independent Effects of Dietary Salt Consumption in Chronic Kidney Disease. Nutrients 2019, 11, 2779. [CrossRef]

124. dietaryguidelines.gov. Dietary Guidelines for Americans 2020-2025. Available online: https://www.dietaryguidelines.gov/ sites/default/files/2020-12/Dietary_Guidelines_for_Americans_2020-2025.pdf (accessed on 23 June 2021). 
125. Campbell, N.R.; Train, E.J. A systematic review of fatalities related to acute ingestion of salt. A need for warning labels? Nutrients 2017, 9, 648. [CrossRef]

126. Ma, J.; Strub, P.; Lv, N.; Xiao, L.; Camargo, C.A.; Buist, A.S.; Lavori, P.W.; Wilson, S.R.; Nadeau, K.C.; Rosas, L.G. Pilot randomised trial of a healthy eating behavioural intervention in uncontrolled asthma. Eur. Respir. J. 2016, 47, 122-132. [CrossRef] [PubMed]

127. Suadicani, P.; Hein, H.O.; Gyntelberg, F. High salt intake and risk of chronic bronchitis: The Copenhagen Male Study-A 10-year followup. ISRN Pulmonol. 2011, 2011, 257979. [CrossRef]

128. Newton, A.H.; Cardani, A.; Braciale, T.J. The host immune response in respiratory virus infection: Balancing virus clearance and immunopathology. Semin. Immunopathol. 2016, 38, 471-482. [CrossRef]

129. Chace, K.V.; Naziruddin, B.; Desai, V.C.; Flux, M.; Sachdev, G.P. Physical properties of purified human respiratory mucus glycoproteins: Effects of sodium chloride concentration on the aggregation properties and shape. Exp. Lung Res. 1989, 15, 721-737. [CrossRef] [PubMed]

130. Fu, Y.; Tong, J.; Meng, F.; Hoeltig, D.; Liu, G.; Yin, X.; Herrler, G. Ciliostasis of airway epithelial cells facilitates influenza A virus infection. Vet. Res. 2018, 49, 65. [CrossRef]

131. Centers for Disease Control and Prevention. Interim Guidelines for Collecting, Handling, and Testing Clinical Specimens from Persons for Coronavirus Disease 2019 (COVID-19). Available online: https://www.cdc.gov/coronavirus/2019-ncov/lab/ guidelines-clinical-specimens.html (accessed on 26 April 2020).

132. Koparal, M.; Kurt, E.; Altuntas, E.E.; Dogan, F. Assessment of mucociliary clearance as an indicator of nasal function in patients with COVID-19: A cross-sectional study. Eur Arch. Otorhinolaryngol. 2021, 278, 1863-1868. [CrossRef] [PubMed]

133. De Freitas, G.; Gudur, A.; Vela-Ortiz, M.; Jodelka, J.; Livert, D.; Krishnamurthy, M. Where there is sodium there may be sepsis. J. Commun. Hosp. Intern. Med. Perspect. 2019, 9, 296-299. [CrossRef]

134. Cereda, D.; Tirani, M.; Rovida, F.; Demicheli, V.; Ajelli, M.; Poletti, P.; Merler, S. The early phase of the COVID-19 outbreak in Lombardy, Italy. arXiv 2020, arXiv:2003.09320.

135. He, X.; Lau, E.H.; Wu, P.; Deng, X.; Wang, J.; Hao, X.; Lau, Y.C.; Wong, J.Y.; Guan, Y.; Tan, X. Temporal dynamics in viral shedding and transmissibility of COVID-19. Nat. Med. 2020, 26, 672-675. [CrossRef] [PubMed]

136. Oran, D.P.; Topol, E.J. Prevalence of asymptomatic SARS-CoV-2 infection: A narrative review. Ann. Intern. Med. 2020, 173, 362-367. [CrossRef]

137. Nalbandian, A.; Sehgal, K.; Gupta, A.; Madhavan, M.V.; McGroder, C.; Stevens, J.S.; Cook, J.R.; Nordvig, A.S.; Shalev, D.; Sehrawat, T.S. Post-acute COVID-19 syndrome. Nat. Med. 2021, 27, 601-615. [CrossRef]

138. Liu, Y.; Yan, L.-M.; Wan, L.; Xiang, T.-X.; Le, A.; Liu, J.-M.; Peiris, M.; Poon, L.L.; Zhang, W. Viral dynamics in mild and severe cases of COVID-19. Lancet Infect. Dis. 2020, 20, 656-657. [CrossRef]

139. webmd.com. Are Warnings Against NSAIDs in COVID-19 Warranted? Available online: https://www.webmd.com/lung/news/ 20200318/ coronavirus-nsaids-experts (accessed on 24 July 2020).

140. Yasir, M.; Goyal, A.; Bansal, P.; Sonthalia, S. Corticosteroid Adverse Effects. Available online: https://www.ncbi.nlm.nih.gov/ books /NBK531462/ (accessed on 24 July 2020).

141. Kim, S.; Joo, K.W. Electrolyte and acid-base disturbances associated with non-steroidal anti-inflammatory drugs. Electrolytes Blood Press. 2007, 5, 116. [CrossRef]

142. Afsar, B.; Kuwabara, M.; Ortiz, A.; Yerlikaya, A.; Siriopol, D.; Covic, A.; Rodriguez-Iturbe, B.; Johnson, R.J.; Kanbay, M. Salt intake and immunity. Hypertension 2018, 72, 19-23. [CrossRef]

143. Matthias, J.; Maul, J.; Noster, R.; Meinl, H.; Chao, Y.-Y.; Gerstenberg, H.; Jeschke, F.; Gasparoni, G.; Welle, A.; Walter, J. Sodium chloride is an ionic checkpoint for human TH2 cells and shapes the atopic skin microenvironment. Sci. Transl. Med. $2019,11$. [CrossRef]

144. Wu, C.; Yosef, N.; Thalhamer, T.; Zhu, C.; Xiao, S.; Kishi, Y.; Regev, A.; Kuchroo, V.K. Induction of pathogenic T H 17 cells by inducible salt-sensing kinase SGK1. Nature 2013, 496, 513-517. [CrossRef]

145. Jantsch, J.; Schatz, V.; Friedrich, D.; Schröder, A.; Kopp, C.; Siegert, I.; Maronna, A.; Wendelborn, D.; Linz, P.; Binger, K.J. Cutaneous $\mathrm{Na}+$ storage strengthens the antimicrobial barrier function of the skin and boosts macrophage-driven host defense. Cell Metab. 2015, 21, 493-501. [CrossRef]

146. Min, B.; Fairchild, R.L. Over-salting ruins the balance of the immune menu. J. Clin. Investig. 2015, 125, 4002-4004. [CrossRef]

147. Vabret, N.; Britton, G.J.; Gruber, C.; Hegde, S.; Kim, J.; Kuksin, M.; Levantovsky, R.; Malle, L.; Moreira, A.; Park, M.D. Immunology of COVID-19: Current state of the science. Immunity 2020, 52, 910-941. [CrossRef]

148. Rubins, J.B. Alveolar macrophages: Wielding the double-edged sword of inflammation. Am. J. Respir. Crit. Care Med. 2003, 167, 103-104. [CrossRef] [PubMed]

149. Berger, R.C.M.; Vassallo, P.F.; de Oliveira Crajoinas, R.; Oliveira, M.L.; Martins, F.L.; Nogueira, B.V.; Motta-Santos, D.; Araújo, I.B.; Forechi, L.; Girardi, A.C.C. Renal effects and underlying molecular mechanisms of long-term salt content diets in spontaneously hypertensive rats. PLOS ONE 2015, 10, e0141288. [CrossRef] [PubMed]

150. Richmond, C. David Tyrrell. BMJ 2005, 330, 1451.

151. Cole, D. New COVID Variants have Changed the Game, and Vaccines will not be Enough. We Need Global 'Maximum Suppression'. Available online: https://theconversation.com/new-covid-variants-have-changed-the-game-and-vaccines-willnot-be-enough-we-need-global-maximum-suppression-157870 (accessed on 4 May 2021). 
152. World Health Organization. Q\&A on Coronaviruses (COVID-19). Available online: https://www.who.int/news-room/q-adetail/ q-a-coronaviruses (accessed on 26 April 2020).

153. Aucott, J.N.; Rebman, A.W. Long-haul COVID: Heed the lessons from other infection-triggered illnesses. Lancet 2021, 397, 967-968. [CrossRef]

154. Hutchin, P.; Terzi, R.; Hollandsworth, L.; Johnson, G., Jr.; Peters, R. Pulmonary congestion following infusion of large fluid loads in thoracic surgical patients. Ann. Thorac. Surg. 1969, 8, 339-347. [CrossRef]

155. Moon, R.E.; Long, R.J. Drowning and near-drowning. Emerg. Med. 2002, 14, 377-386. [CrossRef]

156. Cozzi, D.; Cavigli, E.; Moroni, C.; Smorchkova, O.; Zantonelli, G.; Pradella, S.; Miele, V. Ground-glass opacity (GGO): A review of the differential diagnosis in the era of COVID-19. Jpn. J. Radiol. 2021, 1-12. [CrossRef]

157. Licker, M.; Triponez, F.; Ellenberger, C.; Karenovics, W. Fluid therapy in thoracic surgery: A zero-balance target is always best! Turk. J. Anaesthesiol. Reanim. 2016, 44, 227. [CrossRef]

158. Casas-Aparicio, G.A.; León-Rodríguez, I.; de Jesus Hernandez-Zenteno, R.; Castillejos-López, M.; Alvarado-de la Barrera, C.; Ormsby, C.E.; Reyes-Terán, G. Aggressive fluid accumulation is associated with acute kidney injury and mortality in a cohort of patients with severe pneumonia caused by influenza A H1N1 virus. PLoS ONE 2018, 13, e0192592. [CrossRef] [PubMed]

159. Azzam, Z.S.; Sznajder, J.I. Lung edema clearance: Relevance to patients with lung injury. Rambam Maimonides Med. J. 2015, 6. [CrossRef]

160. Elton, N.W.; Elton, W.J.; Nazareno, J.P. Pathology of acute salt poisoning in infants. Am. J. Clin. Pathol. 1963, 39, $252-264$. [CrossRef]

161. Zhou, F.; Yu, T.; Du, R.; Fan, G.; Liu, Y.; Liu, Z.; Xiang, J.; Wang, Y.; Song, B.; Gu, X. Clinical course and risk factors for mortality of adult inpatients with COVID-19 in Wuhan, China: A retrospective cohort study. Lancet 2020, 395, 1054-1062. [CrossRef]

162. mayoclinic.org. ARDS. Mayo Foundation for Medical Education and Research. Available online: https://www.mayoclinic.org/ diseases-conditions/ards/symptoms-causes/syc-20355576? $\mathrm{p}=1$ (accessed on 26 April 2020).

163. Gattinoni, L.; Coppola, S.; Cressoni, M.; Busana, M.; Chiumello, D. Covid-19 does not lead to a "typical" acute respiratory distress syndrome. Am. J. Respir. Crit. Care Med. 2020, 201, 1299-1300. [CrossRef] [PubMed]

164. Bersten, A.D. Chapter 65. Fluid Management in the Ventilated Patient. In Principles and Practice of Mechanical Ventilation, 3rd ed.; Tobin, M.J., Ed.; The McGraw-Hill Companies: New York, NY, USA, 2013.

165. Begley, S. With Ventilators Running Out, Doctors Say the Machines are Overused for Covid-19. statnews.com. Available online: https:/ / www.statnews.com/2020/04/08/doctors-say-ventilators-overused-for-covid-19/ (accessed on 26 April 2020).

166. Cummings, M.J.; Baldwin, M.R.; Abrams, D.; Jacobson, S.D.; Meyer, B.J.; Balough, E.M.; Aaron, J.G.; Claassen, J.; Rabbani, L.E.; Hastie, J. Epidemiology, clinical course, and outcomes of critically ill adults with COVID-19 in New York City: A prospective cohort study. Lancet 2020, 395, 1763-1770. [CrossRef]

167. Carter, C.; Aedy, H.; Notter, J. COVID-19 disease: Non-Invasive Ventilation and high frequency nasal oxygenation. Clin. Integr. Care 2020, 1, 100006. [CrossRef]

168. Carlson, R.W.; Schaeffer, R.C., Jr.; Michaels, S.G.; Weil, M. Pulmonary edema fluid. Spectrum of features in 37 patients. Circulation 1979, 60, 1161-1169. [CrossRef]

169. Aydin, E.A.; Demir, S.; Aydin, O.; Bilginer, Y.; Ozen, S. Pleural effusion as an atypical presentation of Kawasaki disease: A case report and review of the literature. J. Med. Case Rep. 2019, 13, 344. [CrossRef]

170. mayoclinic.org. Pulmonary Edema. Available online: https://www.mayoclinic.org/diseases-conditions/pulmonary-edema/ symptoms-causes / syc-20377009 (accessed on 26 June 2021).

171. fda.gov. 0.9\% Sodium Chloride Injection. Available online: https://www.accessdata.fda.gov/drugsatfda_docs/label/2017/016 366s214lbl.pdf (accessed on 3 June 2020).

172. rxlist.com. Normal Saline. Available online: https://www.rxlist.com/normal-saline-drug.htm (accessed on 19 April 2021).

173. Semler, M.W.; Self, W.H.; Wanderer, J.P.; Ehrenfeld, J.M.; Wang, L.; Byrne, D.W.; Stollings, J.L.; Kumar, A.B.; Hughes, C.G.; Hernandez, A. Balanced crystalloids versus saline in critically ill adults. New Engl. J. Med. 2018, 378, 829-839. [CrossRef]

174. Long, B.; Brady, W.J.; Koyfman, A.; Gottlieb, M. Cardiovascular complications in COVID-19. Am. J. Emerg. Med. 2020, 38, 1504-1507. [CrossRef]

175. Joseph, S.M.; Cedars, A.M.; Ewald, G.A.; Geltman, E.M.; Mann, D.L. Acute decompensated heart failure: Contemporary medical management. Tex. Heart Inst. J. 2009, 36, 510. [PubMed]

176. Stokes, J.B.; Fraer, M. Volume disorders. In Nephrology Secrets; Elsevier: Amsterdam, The Netherlands, 2012 ; pp. 511-521.

177. WHO. Allergic Rhinitis and Sinusitis. Available online: https://www.who.int/respiratory/other/Rhinitis_sinusitis/en/ (accessed on 3 June 2020).

178. Masood, A.; Moumoulidis, I.; Panesar, J. Acute rhinosinusitis in adults: An update on current management. Postgrad. Med. J. 2007, 83, 402-408. [CrossRef]

179. Gambeta, E.; Chichorro, J.G.; Zamponi, G.W. Trigeminal neuralgia: An overview from pathophysiology to pharmacological treatments. Mol. Pain 2020, 16, 1744806920901890. [CrossRef] [PubMed]

180. Pogoda, J.M.; Gross, N.B.; Arakaki, X.; Fonteh, A.N.; Cowan, R.P.; Harrington, M.G. Severe headache or migraine history is inversely correlated with dietary sodium intake: NHANES 1999-2004. Headache J. Head Face Pain 2016, 56, 688-698. [CrossRef]

181. Stanton, A.A. Migraine Cause and Treatment. Ment. Health Fam. Med. 2015, 11, 69-72. [CrossRef] 
182. Pogoda, J.M.; Gross, N.B.; Arakaki, X.; Fonteh, A.N.; Cowan, R.P.; Harrington, M.G. Severe Headache or Migraine History Is Inversely Correlated with Dietary Sodium Intake: NHANES 1999-2004: A Response. Headache 2016, 56, 1216-1218. [CrossRef]

183. Yeager, A. Lost Smell and Taste Hint COVID-19 can Target the Nervous System. Available online: https://www.the-scientist. com/news-opinion/lost-smell-and-taste-hint-covid-19-can-target-the-nervous-system-67312 (accessed on 3 June 2020).

184. Trescot, A.; Brown, M. Peripheral nerve entrapment, hydrodissection, and neural regenerative strategies. Tech. Reg. Anesth. Pain Manag. 2015, 19, 85-93. [CrossRef]

185. Feldberg, W.; Saxena, P. Mechanism of action of pyrogen. J. Physiol. 1970, 211, 245-261. [CrossRef]

186. Roberts, C.; Noakes, M. Fatal outcome from administration of a salt emetic. Postgrad. Med. J. 1974, 50, 513-515. [CrossRef] [PubMed]

187. drugs.com. Sodium Chloride side Effects. Available online: https://www.drugs.com/sfx/sodium-chloride-side-effects.html (accessed on 4 June 2020).

188. Mirza, F.N.; Malik, A.A.; Omer, S.B.; Sethi, A. Dermatologic manifestations of COVID-19: A comprehensive systematic review. Int. J. Dermatol. 2020, 60, 418-450. [CrossRef]

189. Castells, M.C.; Phillips, E.J. Maintaining Safety with SARS-CoV-2 Vaccines. New Engl. J. Med. 2020, 384, 643-649. [CrossRef] [PubMed]

190. Vaillant, A.A.J.; Vashisht, R.; Zito, P.M. Immediate Hypersensitivity Reactions. Available online: https://www.ncbi.nlm.nih.gov / books /NBK513315/ (accessed on 24 June 2021).

191. Polack, F.P.; Thomas, S.J.; Kitchin, N.; Absalon, J.; Gurtman, A.; Lockhart, S.; Perez, J.L.; Pérez Marc, G.; Moreira, E.D.; Zerbini, C. Safety and efficacy of the BNT162b2 mRNA covid-19 vaccine. New Engl. J. Med. 2020, 383, 2603-2615. [CrossRef] [PubMed]

192. Baden, L.R.; El Sahly, H.M.; Essink, B.; Kotloff, K.; Frey, S.; Novak, R.; Diemert, D.; Spector, S.A.; Rouphael, N.; Creech, C.B. Efficacy and safety of the mRNA-1273 SARS-CoV-2 vaccine. New Engl. J. Med. 2020, 384, 403-416. [CrossRef]

193. Bejaoui, M. Polyethylene glycol as a potential adjuvant treatment for COVID-19-induced ARDS. Authorea Preprints 2020. [CrossRef]

194. cdc.gov. Pfizer-BioNTech COVID-19 Vaccine: Vaccine Preparation. Available online: https://www.cdc.gov/vaccines/covid-19 /info-by-product/pfizer/downloads/diluent-poster.pdf (accessed on 18 July 2021).

195. WHO. Influenza (Seasonal). Available online: https://www.who.int/news-room/fact-sheets/detail/influenza-(seasonal) (accessed on 2 June 2020).

196. Geier, D.A.; Kern, J.K.; Geier, M.R. A longitudinal ecological study of seasonal influenza deaths in relation to climate conditions in the United States from 1999 through 2011. Infect. Ecol. Epidemiol. 2018, 8, 1474708. [CrossRef]

197. Pica, N.; Bouvier, N.M. Environmental factors affecting the transmission of respiratory viruses. Curr. Opin. Virol. 2012, 2, 90-95. [CrossRef]

198. Shahar, D.R.; Froom, P.; Harari, G.; Yerushalmi, N.; Lubin, F.; Kristal-Boneh, E. Changes in dietary intake account for seasonal changes in cardiovascular disease risk factors. Eur. J. Clin. Nutr. 1999, 53, 395-400. [CrossRef]

199. Ersoy, N.; Taşçi, İ.; Özgürtaş, T.; Salih, B.; Doruk, H.; Rakicioğlu, N. Effect of seasonal changes on nutritional status and biochemical parameters in Turkish older adults. Nutr. Res. Pr. 2018, 12, 315-323. [CrossRef]

200. Rossato, S.; Olinto, M.; Henn, R.; Moreira, L.; Camey, S.; Anjos, L.; Wahrlich, V.; Waissmann, W.; Fuchs, F.; Fuchs, S. Seasonal variation in food intake and the interaction effects of sex and age among adults in southern Brazil. Eur. J. Clin. Nutr. 2015, 69, 1015-1022. [CrossRef]

201. Van der Toorn, J.E.; Cepeda, M.; Kiefte-de Jong, J.C.; Franco, O.H.; Voortman, T.; Schoufour, J.D. Seasonal variation of diet quality in a large middle-aged and elderly Dutch population-based cohort. Eur. J. Nutr. 2020, 59, 493-504. [CrossRef] [PubMed]

202. Hashimoto, J.; Imai, Y.; Minami, N.; Munakata, M.; Sakuma, H.; Sekino, H.; Imai, K.; Sasaki, S.; Yoshinaga, K.; Abe, K. Compliance with long-term dietary salt restriction in hypertensive outpatients. Clin. Exp. Hypertens. 1994, 16, 729-739. [CrossRef] [PubMed]

203. Visscher, T.; Seidell, J. Time trends (1993-1997) and seasonal variation in body mass index and waist circumference in the Netherlands. Int. J. Obes. 2004, 28, 1309-1316. [CrossRef] [PubMed]

204. cdc.gov. Sodium and the Dietary Guidelines. Available online: https://www.cdc.gov/salt/pdfs/sodium_dietary_guidelines.pdf (accessed on 27 June 2021).

205. Chen, S.; Prettner, K.; Kuhn, M.; Geldsetzer, P.; Wang, C.; Bärnighausen, T.; Bloom, D.E. Climate and the spread of COVID-19. Sci. Rep. 2021, 11, 1-6.

206. Lam, T.; VoPham, T.; Munger, K.L.; Laden, F.; Hart, J.E. Long-term effects of latitude, ambient temperature, and ultraviolet radiation on the incidence of multiple sclerosis in two cohorts of US women. Environ. Epidemiol. 2020, 4. [CrossRef]

207. Cortese, M.; Yuan, C.; Chitnis, T.; Ascherio, A.; Munger, K.L. No association between dietary sodium intake and the risk of multiple sclerosis. Neurology 2017, 89, 1322-1329. [CrossRef]

208. Whelton, P.K.; Appel, L.J.; Sacco, R.L.; Anderson, C.A.; Antman, E.M.; Campbell, N.; Dunbar, S.B.; Frohlich, E.D.; Hall, J.E.; Jessup, M. Sodium, blood pressure, and cardiovascular disease: Further evidence supporting the American Heart Association sodium reduction recommendations. Circulation 2012, 126, 2880-2889. [CrossRef]

209. Eskandarieh, S.; Heydarpour, P.; Minagar, A.; Pourmand, S.; Sahraian, M.A. Multiple sclerosis epidemiology in east Asia, South East Asia and South Asia: A systematic review. Neuroepidemiology 2016, 46, 209-221. [CrossRef]

210. Bates, G.P.; Miller, V.S. Sweat rate and sodium loss during work in the heat. J. Occup. Med. Toxicol. 2008, 3, 4. [CrossRef]

211. Sigal, C.B.; Dobson, R.L. The effect of salt intake on sweat gland function. J. Investig. Dermatol. 1968, 50, 451-455. [CrossRef] 
212. Nieman, D.C.; Henson, D.A.; Austin, M.D.; Sha, W. Upper respiratory tract infection is reduced in physically fit and active adults. Br. J. Sports Med. 2011, 45, 987-992. [CrossRef]

213. Wimbish, J. NBA Announces Zero Players Tested Positive for COVID-19 Inside Disney Bubble for Fifth Straight Week. Available online: https://www.cbssports.com/nba/news/nba-announces-zero-players-tested-positive-for-covid-19-inside-disneybubble-for-fifth-straight-week/ (accessed on 19 August 2020).

214. Osterberg, K.L.; Horswill, C.A.; Baker, L.B. Pregame urine specific gravity and fluid intake by National Basketball Association players during competition. J. Athl. Train. 2009, 44, 53-57. [CrossRef] [PubMed]

215. Cohen, J.; Pfeiffer, K.; Francis, J.A. Warm Arctic episodes linked with increased frequency of extreme winter weather in the United States. Nat. Commun. 2018, 9, 1-12. [CrossRef]

216. Stuckler, D.; McKee, M.; Ebrahim, S.; Basu, S. Manufacturing epidemics: The role of global producers in increased consumption of unhealthy commodities including processed foods, alcohol, and tobacco. PLoS Med. 2012, 9, e1001235. [CrossRef] [PubMed]

217. Moodie, R.; Stuckler, D.; Monteiro, C.; Sheron, N.; Neal, B.; Thamarangsi, T.; Lincoln, P.; Casswell, S.; Group, L.N.A. Profits and pandemics: Prevention of harmful effects of tobacco, alcohol, and ultra-processed food and drink industries. Lancet 2013, 381, 670-679. [CrossRef]

218. zupreem.com. Exotic Feline Diet Canned. Available online: https://www.zupreem.com/products/zoo-animals/exotic-feline/ (accessed on 26 April 2020).

219. Animal and Plant Health Inspection Service, United States Department of Agriculture. USDA Statement on the Confimation of COVID-19 in a Tiger in New York. Available online: https://www.aphis.usda.gov/aphis/newsroom/news/sa_by_date/sa-2020 /ny-zoo-covid-19 (accessed on 26 April 2020).

220. Everts, S. Processed: Food Science and the Modern Meal. Available online: https://www.sciencehistory.org/distillations / processed-food-science-and-the-modern-meal (accessed on 4 June 2020).

221. bbc.com.uk. What did People Eat During World War One? Available online: https://www.bbc.co.uk/bitesize/topics/zqhyb9q/ articles / z8kv34j (accessed on 4 June 2020).

222. Roos, D. Why the Second Wave of the 1918 Spanish Flu was so Deadly. Available online: https://www.history.com/news / spanish-flu-second-wave-resurgence (accessed on 4 June 2020).

223. Taubenberger, J.K.; Morens, D.M. 1918 Influenza: The mother of all pandemics. Rev. Biomed. 2006, 17, 69-79. [CrossRef]

224. Maver, M.B. Nutritional edema and war dropsy. J. Am. Med. Assoc. 1920, 74, 934-941. [CrossRef]

225. Shope, R.E. Influenza: History, epidemiology, and speculation: The RE Dyer lecture. Public Health Rep. 1958, 73, 165. [CrossRef]

226. Patrozou, E.; Mermel, L.A. Does influenza transmission occur from asymptomatic infection or prior to symptom onset? Public Health Rep. 2009, 124, 193-196. [CrossRef]

227. Savvides, C.; Siegel, R. Asymptomatic and presymptomatic transmission of SARS-CoV-2: A systematic review. Medrxiv: Prepr. Serv. Health Sci. 2020. [CrossRef]

228. cdc.gov. How Flu Spreads. Available online: https:/ /www.cdc.gov/flu/about/disease/spread.htm (accessed on 27 June 2021).

229. Sanjuán, R. Collective Infectious Units in Viruses. Trends Microbiol. 2017, 25, 402-412. [CrossRef]

230. Hobday, R.A.; Cason, J.W. The open-air treatment of pandemic influenza. Am. J. Public Health 2009, 99, S236-S242. [CrossRef]

231. Ernst, E.; Pecho, E.; Wirz, P.; Saradeth, T. Regular sauna bathing and the incidence of common colds. Ann. Med. 1990, 22, 225-227. [CrossRef]

232. Zaccardi, F.; Laukkanen, T.; Willeit, P.; Kunutsor, S.K.; Kauhanen, J.; Laukkanen, J.A. Sauna bathing and incident hypertension: A prospective cohort study. Am. J. Hypertens. 2017, 30, 1120-1125. [CrossRef]

233. Fictum, D. Salt Pork, Ship's Biscuit, and Burgoo: Sea Provisions for Common Sailors and Pirates. Available online: https:// csphistorical.com/2016/01/24/salt-pork-ships-biscuit-and-burgoo-sea-provisions-for-common-sailors-and-pirates-part-1/ (accessed on 9 February 2021).

234. Price, C. The Age of Scurvy. Available online: https://www.sciencehistory.org/distillations/magazine/the-age-of-scurvy (accessed on 9 February 2021).

235. McCann, A.W. Two Hundred and Fifty-Five Days! In This Famishing World; George H. Doran Company: New York, NY, USA, 1918.

236. Mallapaty, S. What the cruise-ship outbreaks reveal about COVID-19. Nature 2020, 580, 18. [CrossRef]

237. Lau, Y.-Y.; Yip, T.L. The procurement of food on board liner ships: The role of the international labor organization. J. Shipp. Trade 2017, 2, 6. [CrossRef]

238. Stein, R.A.; Ometa, O. When Public Health Crises Collide: Social Disparities and COVID-19. Int. J. Clin. Pract. 2020, e13524. [CrossRef]

239. De Mestral, C.; Mayén, A.-L.; Petrovic, D.; Marques-Vidal, P.; Bochud, M.; Stringhini, S. Socioeconomic determinants of sodium intake in adult populations of high-income countries: A systematic review and meta-analysis. Am. J. Public Health 2017, 107, e1-e12. [CrossRef]

240. Kakol, M.; Upson, D.; Sood, A. Susceptibility of Southwestern American Indian Tribes to Coronavirus Disease 2019 (COVID-19). J. Rural Health. 2021, 37, 197-199. [CrossRef]

241. Lansbury, L.E.; Brown, C.S.; Nguyen-Van-Tam, J.S. Influenza in long-term care facilities. Influenza Other Respir. Viruses 2017, 11, 356-366. [CrossRef]

242. Barnett, M.L.; Grabowski, D.C. Nursing homes are ground zero for COVID-19 pandemic. JAMA Health Forum 2020,1 , e200369. [CrossRef] 
243. Dharmarajan, T.S.; Manalo, M.; Manalac, M.; Kanagala, M. Hypothermia in the nursing home: Adverse outcomes in two older men. J. Am. Med. Dir. Assoc. 2001, 2, 29-33. [CrossRef]

244. Hawks, L.; Woolhandler, S.; McCormick, D. COVID-19 in Prisons and Jails in the United States. JAMA Intern. Med. 2020, 180, 1041-1042. [CrossRef]

245. Mintz, C. Food in Hospitals and Prisons is Terrible-But it doesn't have to be that Way. Available online: https: //www.theglobeandmail.com/life/food-and-wine/food-trends/food-in-hospitals-prisons-is-notoriously-bad-but-it-doesnthave-to-be-that-way/article29951216/ (accessed on 4 June 2020). 